\title{
Pandillas, jóvenes y violencia
}

\author{
Héctor Castillo Berthier
}

¿Quién podría no tener una opinión sobre los incrementos de la delincuencia en las calles? ¿Quién no concuerda con la idea de lo que supuestamente es hoy la juventud y con lo que se piensa que está sucediendo con este importante grupo social? Los estudios sociales han presentado diferentes rostros de este fenómeno y, aunque han formulado propuestas para la reintegración de estos grupos juveniles hoy surge una duda: ia qué sociedad se les quiere integrar si nunca han pertenecido a ella? Es un hecho que actualmente las políticas sociales de los gobiernos están en general disociadas y, muchas veces, en abierto antagonismo a los esfuerzos realizados desde la sociedad civil: iha llegado el momento de replantear el papel del Estado frente a la caótica realidad existente? Existen barrios donde la violencia es una forma de vida y los residentes tienen que adoptar esa actitud, es decir, combaten violencia con violencia: ¿no es posible conjugar los conceptos de juventud y cultura con la definición de una política social pública que prevea estos escenarios? El presente trabajo pretende dar respuesta a algunas de estas interrogantes.

Is there anyone who could have no opinion regarding the increase of delinquency in the streets? Is there anyone who does not agree with the idea on what young people are supposedly today and with what is believed to be happening in this important social group? Social studies have presented different angles of this phenomena and, in spite of proposals being formulated for the reintegration of these juvenile groups a doubt now emerges. To which society does one wish to integrate them if they have never belonged to one? It is a fact that, at present, government social policies are in general dissociated from and, often, in open antagonism to the efforts carried out by the civil society. Has the time come to rethink the role of the State vis-à-vis the existing chaotic reality? There are neighborhoods where violence is a way of life and the residents have to adopt this attitude to combat violence with violence. Is it not possible to join the concepts of youth and culture with the definition of a public social policy which foresees these scenarios? This article seeks to answer some of these questions.

HÉCTOR CASTILLO BERTHIER: Instituto de Investigaciones Sociales de la UNAM.

Desacatos, núm. 14, primavera-verano 2004, pp. 105-126. 


\section{¿DÓNDE ESTAMOS?}

$\mathrm{M}$

aras, clicas, bandas, pandillas, parches, gangas; $y$ sus miembros: gamines, homies, parceros, pivetes, sicarios; con sus arengas: "por el barrio nací, por el barrio moriré", "el enemigo es la ley", “jamor del Rey!”; con las ropas de colores diferenciados y exclusivos; con los tatuajes como símbolos de identidad: tres puntos en el antebrazo o entre los dedos pulgar e índice que significan "dinero, drogas y mujeres", las cruces en el pecho o las lágrimas en los ojos que indican el número de muertos, y esa clásica leyenda en el cuello, en el pecho o en la espalda: "Perdóname madre mía por mi vida loca”. Y sus nombres: la Vida Loca, la Blood for Blood (sangre por sangre), la Denfo du Barrio (morir por el barrio), la MM (Mexican Mafia), la Mara 13, la 18, los Panochos, la 21, los Salvatrucha... son sólo algunos cuantos de los nuevos símbolos de una vieja realidad: organizaciones de autodefensa juveniles en "territorios enemigos", donde ser joven pobre - y más si es migrante- tiene un alto costo de discriminación; donde la única "salida" a

la marginalidad tiene que romper la ley; donde la violencia, propia del sistema capitalista, es enfrentada con más violencia; donde la vida no vale nada, o más bien, donde se da el encuentro de la funesta realidad de saber que la muerte comienza a ser un negocio lucrativo.

Y los países: Guatemala, Honduras, Nicaragua, Colombia, Brasil, El Salvador, Costa Rica, Panamá, México, y otros más, en donde se está gestando una auténtica unificación latinoamericana respecto a la existencia de estos jóvenes pandilleros que, más allá de la búsqueda de una identidad o del consumo y asimilación de la hibridación cultural globalizada, han encontrado en la violencia una forma para tratar de sobrevivir en una sociedad de la cual han estado excluidos permanentemente.

Si en general a los años 1980 se les calificó como la década perdida, los jóvenes de estos años pasaron a ser automáticamente una generación perdida, hijos (o nietos) de las recurrentes crisis económicas y de gobierno; pero en Centroamérica, y con mayor fuerza en Nicaragua y El Salvador, sus jóvenes fueron, además, hijos de la guerra.

El Salvador es considerado por la Organización de las Naciones Unidas (ONU) como el segundo lugar más vio- lento de Latinoamérica, después de Colombia y es en este país donde el nombre de una pandilla en particular, la Mara Salvatrucha, empieza poco a poco a invadir la realidad de otros países y obliga a voltear la mirada sobre un problema que, si bien siempre ha existido, hoy reaparece con una fuerza y una violencia nunca antes vista, en medio de un ambiente expansivo y de exportación del fenómeno hacia los países vecinos.

Vale la pena detenernos en una declaración reciente de la Fiscalía General de la República (FGR) de El Salvador, en voz de su director, Belisario Artiga, quien reconoce que los distintos gobiernos salvadoreños "dejaron crecer el problema de los mareros". Una vez terminada la guerra en 1992, El Salvador entró en un lento proceso de reconstrucción que incluyó nuevas leyes y el desarme obligatorio de todos los grupos armados, y agrega:

\section{Nadie vislumbró lo que significaba la época de la posgue- rra y se cometieron errores... Al desmovilizarse los cuer- pos de seguridad y la guerrilla, se dejó suelta a una masa de 40000 hombres que durante 15 años aprendieron a defen- derse o matar y que de lo único que sabían era de armas... la Policía Nacional Civil (PNC) era un cuerpo amorfo que no estaba preparado para controlar la delincuencia urbana [que es] muy diferente al combate en las montañas... La economía estaba desecha y en cero la creación de empleos.. Por esos años el gobierno estadounidense inició la depor- tación masiva de salvadoreños que estaban en prisión o cometieron algún delito en las calles... Llegaron miles, sin control alguno. Jamás supimos quiénes eran o si tenían an- tecedentes penales; muchos de ellos venían directamente de la prisión y como no habían cometido delitos aquí, al lle- gar al aeropuerto quedaban libres, se iban a las pandillas. ${ }^{1}$}

En los primeros años de la posguerra las maras pasaron desapercibidas y semi ocultas en el torbellino de la delincuencia urbana. "Las prioridades eran otras — reconoce el fiscal—, teníamos una alta incidencia de asaltos a mano armada, robo de bancos, de furgones con mercancía y de secuestros exprés, que por cierto vinieron de México" (ibid.). Y no fue sino hasta 10 años después, en el 2002,

\footnotetext{
1 "La vida en territorio mara", La Jornada, suplemento Masiosare, 7 de marzo de 2004, pp. 5-9.
} 
cuando el gobierno salvadoreño empezó a aplicar ciertas "medidas"; pero el problema ya estaba fuera de control. Entre estas medidas sobresalen dos en particular: la llamada "Ley Antimaras", que parece tener más bien una orientación política —ya que es impulsada por el presidente y su partido antes de las elecciones y termina tres semanas después de que estas sucedan-, y el programa "Mano Dura" que, entre sus objetivos, prohíbe pertenecer a pandillas, usar tatuajes, reunirse en la calle con más de dos personas, además de aplicar sanciones penales a menores de edad.

Los resultados de dichas medidas son similares a los que ocurren en muchos otros países con situaciones análogas: miles de detenidos — 10 178 en el caso de El Salvador de un total estimado por la PNC de 11000 pandilleros distribuidos en 309 clicas-, $81 \%$ de ellos por sospechas de pertenecer a las maras o por traer algún tatuaje, de los que sólo al 14\% se les relacionó con algún delito cometido por las pandillas y que arroja una cifra implacable: 95\% de los detenidos están libres por falta de pruebas (ibid.). ¿Qué nos dicen estas cifras sobre el problema?, ¿puede verse una manipulación del fenómeno social para sacar alguna ventaja política?, ¿no parece acaso que los jóvenes siguen siendo "carne de cañón" para ser utilizados sólo en las épocas electorales vía la manipulación de sus estigmas en los medios?, ¿cuál es el verdadero alcance de estas disposiciones del estilo "Cero Tolerancia"?

No es posible hablar de los jóvenes en términos maniqueístas para decir que todos son buenos o, al contrario, malos. Es natural que en los grupos sociales haya una mezcla indeterminada de los dos tipos, subordinada a las condiciones de vida materiales y sociales. Sin embargo, y paralelamente a la "efectividad" de estas medidas — anunciadas sistemáticamente en la prensa para alcanzar el objetivo mediático deseado- , surge en la sociedad un sentimiento y una percepción de "lo que son los jóvenes",

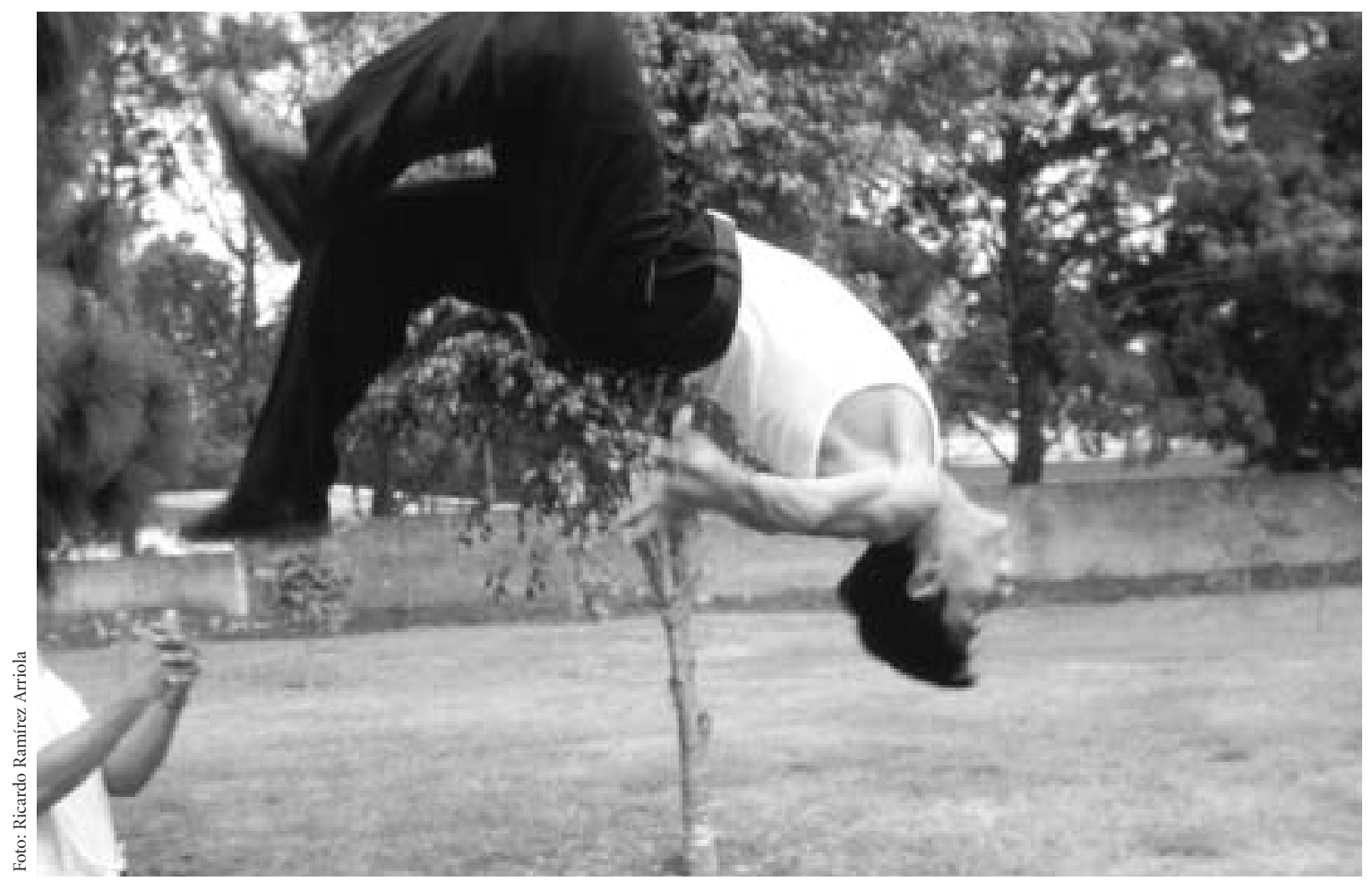

"El momento más doloroso fue cuando mataron a mi hermanita de dos años. Fue en una esquina. Pasaron disparando. Yo estaba cerca con unos homies." 


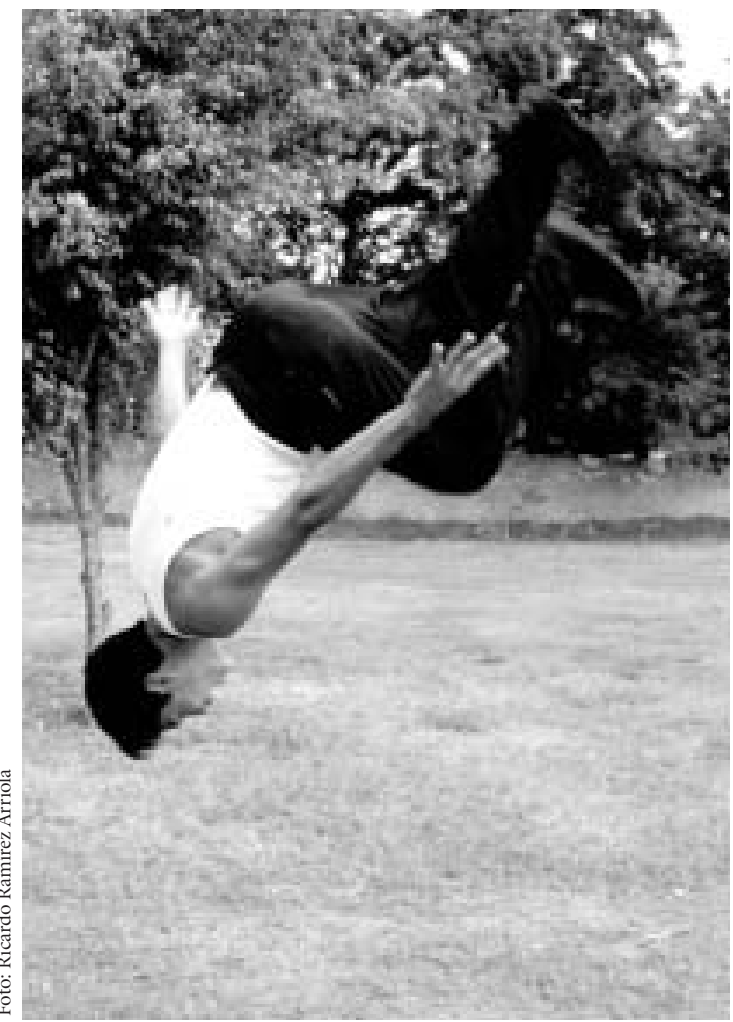

"No, yo cuando estaba con aquéllos nunca tuve miedo de todo eso, pero ahora sí porque me he puesto a pensar que la vida pues es bonita."

del peligro que representan y que muchas veces la lleva a actuar en forma violenta e irracional, amparada por la inexistencia de "justicia" o la presencia de un estado de derecho débil y sin bases sólidas.

Así, surgen en Brasil los "Escuadrones de la Muerte", en Colombia la "Policía Cívica", en El Salvador la "Sombra Negra”, que inician, por su cuenta, auténticas "operaciones de limpieza”, asesinando a los pandilleros — $\mathrm{O}$ a quienes creen ellos que lo son-, aumentando el clima de violencia y de impunidad que permite que todas estas manifestaciones de barbarie sean, paradójicamente, "aceptadas” e incluso validadas por una buena parte de la sociedad. El concejal del ayuntamiento del Gran Salvador y durante nueve años combatiente activo del Frente Farabundo Martí de Liberación Nacional (FMLN), Eduardo Linares, ha dicho respecto a las fotografías de cadáveres desmembrados que aparecen en un reporte de la policía:
Era la forma de amedrentar a la gente en los años de la guerra sucia... Decapitar personas y tirar la cabeza en sitios diferentes, o desmembrar varios cuerpos y juntar las partes de todos en un solo lugar fue el sello de la dictadura... Se han encontrado jóvenes amarrados, colgados de los pulgares como en los tiempos de la guerra. Eso no lo hacen los mareros, no es su metodología, y por el contrario, queda la sensación de que hay operativos para limpiar al país de las maras (ibid.).

La difusión de estas imágenes por los medios de comunicación dieron el sustento para la aplicación de las "medidas" en contra de las pandillas. Sin embargo, para los jóvenes pandilleros, su grupo —su "familia" — sigue siendo una parte medular de su existencia, en donde ser pandillero significa ser solidario, alimentar a otro pandillero o asesinar por tu pandilla. Es decir que ser pandillero está considerado por muchos como una auténtica forma de vida.

Miles de jóvenes — literalmente hablando — se han sumado a las maras de El Salvador, pero no se trata de un fenómeno local, lo mismo ha ocurrido en Colombia, Los Ángeles, Nueva York, Nicaragua, Honduras o México, y una de las advertencias de un marero indica que tan sólo en la ciudad de México ya existen unos 1300 mareros distribuidos en siete clicas, que son la columna vertebral de los Salvatrucha en este país, advirtiendo que si hoy se preocupan de que estén llegando tantos pandilleros "no han visto nada todavía" (ibid.).

Un marco general que unifica las realidades específicas de estos países es la pobreza generalizada y sus efectos en la población, que es hoy una discusión de primer nivel para los países de América Latina, debido al considerable aumento de este fenómeno social y económico. Algo que contribuye al debate es que la pobreza se ha dado en medio de un contexto de raquítico crecimiento de la economía, caracterizado a la vez por un proceso de remodelación radical del papel del Estado en relación con las políticas sociales o de bienestar.

Junto al tema de la pobreza aparecen nuevas concepciones de la privación: vulnerabilidad, exclusión, discriminación, explotación y violencia. Algunos de éstos son temas viejos en las ciencias sociales, pero olvidados o evitados por ciertos paradigmas científicos disciplinarios. 
Pero la magnitud de las desigualdades con relación a las clases sociales, las razas, géneros, edades y regiones, hacen que estos tópicos vuelvan a plantearse como pertinentes en la discusión de las formas de inequidad social.

Por estas razones es necesario ampliar el debate sobre la pobreza y sus diversas manifestaciones, así como la concepción y materialización de las políticas sociales en torno a este tema. Es urgente expandir el debate de la pobreza —entendida no sólo como carencia económica- hacia la comprensión de la miseria como elemento clave para la construcción de prácticas sociales que buscan enfrentar de raíz las necesidades del individuo, la familia o la colectividad. Esta tarea implica una perspectiva multidisciplinaria, por lo que el tema de la metodología de estudio y de la reflexión normativa resultan indispensables en una discusión que abra nuevos horizontes a la investigación social.

"Pandillas, jóvenes, violencia", estos conceptos unidos encierran un tema que es común a la realidad de muchos países, no sólo de América Latina sino del mundo entero: la delincuencia juvenil. Su presencia es recurrente y ofrece, contradictoriamente, las visiones convergentes y en cierta forma engañosas que aparecen día con día en los medios de comunicación, en las oficinas de gobierno donde se diseñan las políticas públicas y en los frecuentes temas de conversación de las reuniones familiares. ¿Quién podría no tener una opinión sobre los incrementos de la delincuencia en las calles?, ¿quién podría abstenerse de reflexionar — aunque sea superficialmente- sobre lo que son y representan las bandas y las pandillas juveniles en su ciudad o en su barrio?, ¿quién no tiene una idea cercana a lo que supuestamente es hoy la juventud y a lo que se cree está sucediendo con este importante grupo social?

La interacción de estos conceptos, sin un análisis de mayor alcance, fácilmente permite imaginar escenarios caóticos, plagados de lugares comunes y muchas veces oscuros, como si se tratara de un túnel prefabricado en donde ya se sabe — $\mathrm{O}$ al menos se intuye con toda seguridad- "lo que va a ocurrir". Pero, curiosamente, tanto la juventud como las pandillas o la violencia son categorías que necesitan de una indispensable reconstrucción histórica de acuerdo con los parámetros específicos de cada sociedad, si es que se quiere entender — en un sentido extenso- el presente y el futuro de nuestra sociedad contemporánea, donde de seguir con las actuales tendencias demográficas, al menos en América Latina, habrá en las dos siguientes décadas más jóvenes que nunca antes en toda la historia del continente.

Los pandilleros recrean una serie de símbolos identitarios que les permiten crear sus propios códigos de comunicación con un solo objetivo: diferenciarse e integrarse a "algo" que ha venido a suplir el papel de la familia.

Pero no todo está perdido, y agrupaciones como los Homies Unidos, en la ciudad de El Salvador, o Circo Volador en México, se han reunido para buscar en las pandillas, en las bandas, las fortalezas y habilidades que les permitan transformarse en personas productivas y de paso dar una solución al problema de la violencia social existente. Junto a ellas están los programas y las políticas sociales que surgen del gobierno, como es el caso de los partidos de futbol nocturnos organizados en El Salvador por el Consejo de Seguridad. Ante esto, Luis Romero de Homies Unidos plantea: “ $¿ D e$ qué sirve jugar al futbol si en la noche me voy a morir de hambre?” (ibid.). O sea, ¿a qué sociedad se les quiere integrar si nunca han pertenecido a ella? Es un hecho que actualmente las políticas sociales de los gobiernos están en general disociadas, separadas y, muchas veces, en abierto antagonismo frente a los esfuerzos realizados desde la sociedad civil: ¿qué quiere decir esto?, ¿no es acaso el momento de replantear seriamente el papel del Estado frente a la caótica realidad existente?, ¿seguirá vigente el viejo lema de las bandas "no hay futuro"?, ¿hasta cuándo? En los siguientes apartados se pretende obtener alguna respuesta a estas interrogantes.

\section{PANDILLAS: UNA PERSPECTIVA SOCIOLÓGICA}

Como grupo social, los jóvenes están forzosamente vinculados a su entorno, al ambiente económico, social, político y cultural presente en cualquier etapa de la historia de un país o de una ciudad, y de esta relación histórica dependerán los mecanismos, acuerdos, visiones y formas de convivencia que se hayan establecido entre ellos y su sociedad; de ella también dependerá la imagen pública 
de los jóvenes, su percepción popular y las formas y límites que encontraron para asociarse entre sí, en cualquier contexto. Los jóvenes no son un grupo homogéneo, más bien el concepto juventud encierra en sí mismo la suma de numerosos grupos, muy distintos entre sí, que algunas veces llegan a ser hasta antagónicos. Por ejemplo, es un hecho que no todos los deportistas son jóvenes y que no todos los jóvenes son deportistas; sin embargo, el deporte es una actividad ligada intrínsecamente a la juventud. De la misma forma, no todos los jóvenes son delincuentes ni todos los delincuentes son jóvenes, pero, al igual que en el ejemplo anterior, existe cierta tendencia construida socialmente que, con frecuencia, relaciona estos dos conceptos hasta llegar a hablar específicamente de una "delincuencia juvenil": ¿qué tan real es esta percepción?, ¿es sano para una sociedad pensar así de sus "hombres y mujeres del mañana"?, ¿cuáles son los efectos que tienen este tipo de interpretaciones sociales?

Los motivos del surgimiento de estas percepciones sobre los jóvenes son múltiples y de orígenes diversos, sin embargo, es un hecho - aceptado actualmente en las ciencias sociales- que respecto a este sector en particular existe una estigmatización que, con los años, se ha visto reforzada y muy difundida por los medios masivos de comunicación. ¿De dónde han surgido estas visiones?, ¿existe acaso una estrategia perversa para marcarlos deliberadamente?, ¿quiénes han sido los responsables de este complejo proceso de etiquetación social?, ¿hacia dónde se dirige este fenómeno y que resultados arroja? En este pequeño apartado se pretenden describir los momentos más sobresalientes de la historia reciente de este conflicto, en el cual la relación ciencias sociales-juventud ha dejado huellas visibles que, finalmente, han llevado a la construcción de un concepto de "juventud" vinculado a las características que ahora se tienen respecto a las pandillas, las bandas y la violencia, a las que parece estar irremediablemente unido, de la misma forma que al deporte o la delincuencia.

El estudio de las pandillas y las bandas juveniles tiene una larga historia que suma ya poco más de ocho décadas en los países del primer mundo, donde con todo cuidado y detalle se empezaron a describir las diferentes formas de integración y de interacción social de los jóvenes dentro y alrededor de sus grupos de pertenencia. Podría decirse que dichos trabajos pioneros se encontraban en general circunscritos a una demanda específica de los gobiernos en turno, de los empresarios o en general de las esferas de poder, que trataban de entender y prever los diferentes escenarios de consolidación de sus clases populares juveniles, muchas de ellas compuestas por familias de inmigrantes.

Casi desde el principio del siglo pasado en Estados Unidos la migración estuvo ligada a las acciones de medición y control de los impactos negativos y notorios - que se reflejaban en la formación de pandillas o gangs - en los barrios donde se asentaban los nuevos ciudadanos. Debe decirse que, ante todo, la formación de estos grupos de encuentro de los jóvenes obedecieron en muchos casos a mecanismos primarios de defensa ante el racismo o la agresión directa de los residentes locales en contra de los recién llegados. Seguramente existen también otros aspectos en este fenómeno, como serían los sentimientos nacionalistas, las costumbres de sus lugares de origen o hasta sus características étnicas, pero bien se puede afirmar que el llamado pandillerismo se origina, al menos en la visión de las ciencias sociales de Occidente, con los jóvenes que emigraron, o bien con los hijos e hijas de las familias migrantes. En América Latina, y en general en los países del llamado Tercer Mundo, este tipo de trabajo son escasos, cuando no completamente inexistentes. De hecho, las ciencias sociales en nuestros países empezaron a preocuparse por esta problemática a finales de la década de 1960. Lo hicieron trasladando directamente algunos de los modelos analíticos ya desarrollados y, curiosamente, muchas de estas investigaciones se originaron también a partir de la demanda de los gobiernos que entonces comenzaban a interesarse en los jóvenes por su aspecto, su rechazo al sistema, su rebeldía, todo aquéllo, con el interés de diseñar nuevas medidas de control o de atención dentro de las políticas públicas.

Entre los trabajos iniciales sobre esta temática desarrollada en los países centrales está el libro de Adams Puffer, The Boy and his Gang (El niño y su pandilla), ${ }^{2}$ el hoy

2 J. Adams Puffer, The Boy and his Gang, Houghton Mifflin Company, Boston, 1912. 
clásico Gangs of New York (Pandillas de Nueva York) de Herbert Asbury, ${ }^{3}$ que muy recientemente se transformó en una exitosa película de Hollywood. Otros trabajos similares son los de Thrasher, The Gang (La pandilla); ${ }^{4} \mathrm{de}$ Shaw, The Jack Roller; 5 y el conocido libro de William Foote White, Street Corner Society ${ }^{6}$ (La sociedad de las esquinas). En estos libros, el trabajo de investigación estuvo enfocado a mostrar los nexos de amistad, individuales, ocasionales, de compromiso racial o de pertenencia a un barrio específico, que permitían a los jóvenes de esos tiempos desarrollar mecanismos bien definidos para establecer su interrelación entre sí y frente a su entorno. En Europa, Eduardo Spranger, en su libro Psicología de la edad juvenil, 7 hablaba de la pandilla como el umbral que marcaba el ingreso de los adolescentes a la sociedad, bajo toda una serie de códigos y ritos que debían cumplir para lograr tal propósito.

De estos trabajos, quizá el estudio más profundo sobre la juventud como una forma de interacción social es el de Whyte, que describe y analiza la vida de un barrio pobre de inmigrantes a finales de la década de 1930. El tema de este estudio se centra en la interacción entre jóvenes, la importancia de esta interacción entre los individuos y sus relaciones con la profesión, la asistencia social y la política. Whyte ofrece un cuadro vivo de la asociación voluntaria entre los jóvenes de Cornerville, misma que se caracteriza por ser una estructura marcadamente informal de pandillas débilmente integradas, compuestas por pequeños grupos de muchachos, pero creando simultáneamente una estructura claramente jerárquica en términos de influencia y prestigio. De ahí que la aceptación y participación en estos grupos fuera decisiva para lograr un cierto equilibrio de las personalidades individuales. En el trabajo se divide a las pandillas en dos grandes grupos: "los muchachos de la calle" y "los muchachos de

\footnotetext{
${ }^{3}$ Herbert Asbury, Gangs of New York, Garden City Publishing Company, Nueva York, 1927.

${ }^{4}$ F. Thrasher, The Gang, University of Chicago Press, Chicago, 1927.

${ }^{5}$ C. R. Shaw, The Jack-Roller, University of Chicago Press, Chicago, 1930

${ }^{6}$ William Foote Whyte, Street Corner Society: The Social Structure of an Italian Slum, University of Chicago Press, Chicago, 1943.

7 E. Spranger, Psicología de la edad juvenil, Revista de Occidente, Madrid, 1929
}

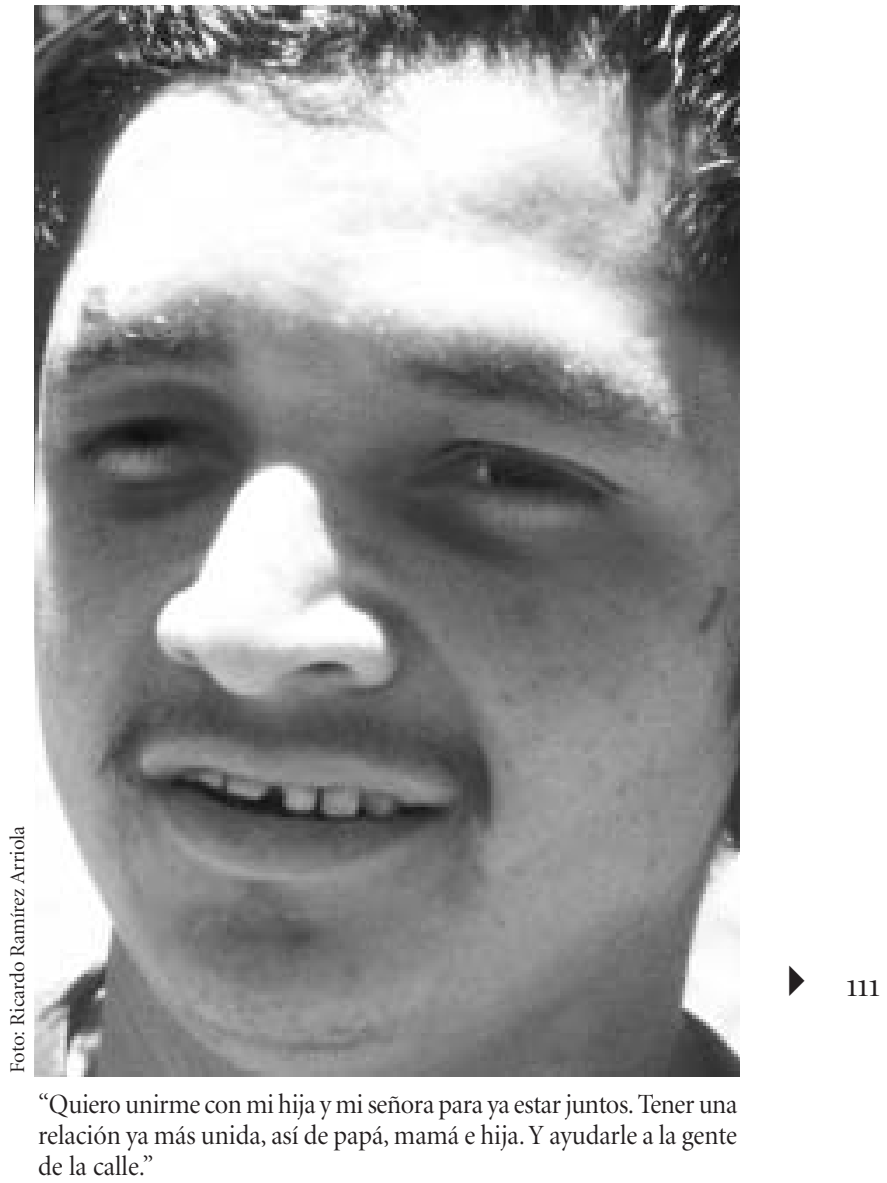

la escuela", que presentaban rasgos diferenciados y expectativas de vida radicalmente opuestas.

Durante la década de 1940 la sociología estadounidense había logrado establecer una cierta imagen afectiva y, hasta cierto punto, positiva de las pandillas, ya que se aseguraba que estas agrupaciones apoyaban algunas de las experiencias primarias para favorecer la socialización de los jóvenes dentro del modelo económico, político y social de la sociedad. Se argumentaba: "Las pandillas constituyen agrupamientos espontáneos de adolescentes y jóvenes, motivados por la necesidad de organizar algunas parcelas de sus vidas dentro de una rama afectiva de asociación. Dentro de la pandilla, el joven aprende a superar sus frustraciones, a conocer y a respetar unas reglas de juego limpio para convivir y la aceptación de una 


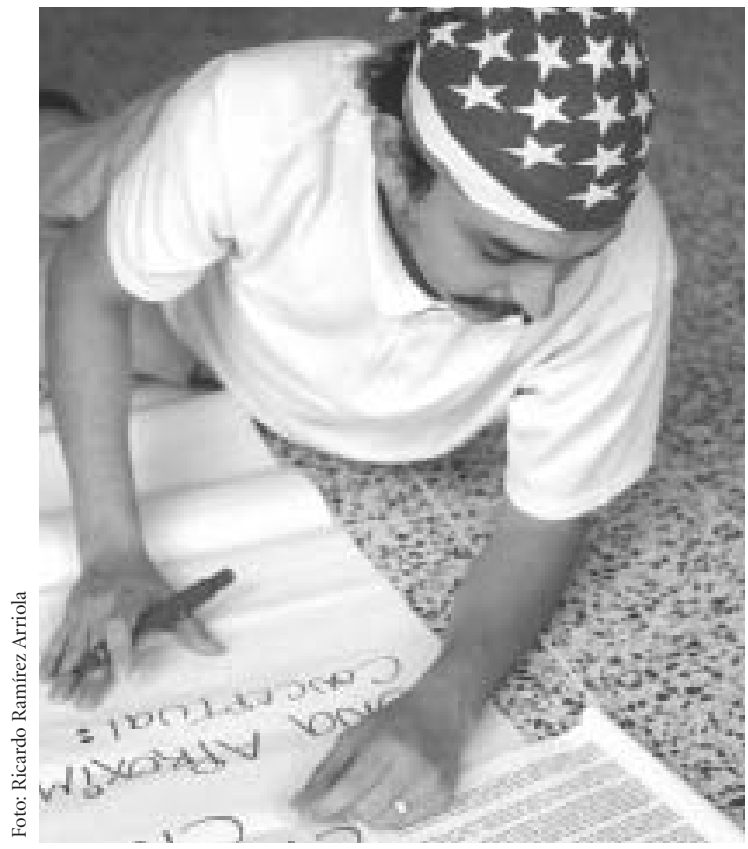

"Ella me decía: ¡Te querés casar conmigo? Pero, ¿qué va a pasar cuando tengamos hijos y tú en la pandilla y te maten?"

ética inflexible que le llevará a saber adaptarse a situaciones nuevas."

Para algunos autores esta visión positiva, que subraya el papel afectivo de las pandillas, oculta un trasfondo vinculado al carácter competitivo de los individuos en que está fundamentado el desarrollo capitalista. El trasfondo de semejante interés por resaltar el papel afectivo de la pandilla lo señala G. Pearson —aunque también de una manera bastante tangencial, por no decir ideológica—:

La cultura occidental acentúa como ideal el derecho que el individuo tiene de poseer sus propias ideas sobre la religión, la política, la elección de su propia vocación, la soledad y muchas otras cosas.

Si cambiamos el término libre decisión propuesto por el capitalismo liberal, por entrenamiento a la decisión consumista del neocapitalismo, entendemos mejor este sig-

${ }^{8}$ Esteban Mestre, "Pandilla", Diccionario de ciencias sociales, IEP, Madrid, 1976, p. 423 . nificado y podemos captar el sentido de los siguientes párrafos:

Para poder fortalecer su ego y proporcionarse confianza a sí mismo, se alía el joven con un grupo de sus pares. Se incorpora a una pandilla que puede ser un grupo de cowboys callejeros, una pandilla de esquina, o de boy scouts u otra clase de grupo socialmente autorizado; y entonces comienza a sentir la solidaridad que le proporciona ser exactamente igual que el resto de su grupo, quien [que] siempre tiene las siguientes características: ritos de iniciación, cohesión dentro del mismo; una actitud de rivalidad hacia todos los demás grupos; la exigencia de que cada uno de los miembros siga todas las costumbres y modales del grupo y, en particular, que cada miembro del grupo desconfíe de todos los adultos, aún si al hacerlo se ve obligado a enfrentarse abiertamente a sus padres [...] Esta actitud rebelde del grupo hacia la organización social es provechosa y necesaria, pues cuando el adolescente se convierte en adulto, lo incita a realizar esfuerzos tendientes a cambiar fundamentalmente las normas consuetudinarias de la organización social, a descartar aquellos aspectos que han pasado de moda y sustituirlos por nuevas costumbres que están más en consonancia con las realidades contemporáneas. ${ }^{9}$

Según esta interpretación, las pandillas serían especies de clubes que permitirían capacitar a los adolescentes en un ambiente competitivo, imbuidos además en una ideología del cambio y la superación personal y con una independencia en la toma de decisiones que el sistema capitalista demanda como "regla imperativa del juego".

Pese a esta visión "optimista" de una juventud fácilmente reciclable, otros autores mencionan que frente a estos grupos de "niños normales", ligados entre sí por fuertes vínculos externos como pueden ser las familias, las escuelas o incluso los clubes deportivos, también existe la posibilidad de que surjan pandillas de inadaptados o frustrados sociales, que inician sus nexos a edades muy tempranas y fundamentalmente en las calles, quienes necesitan de esta amistad callejera de otros como ellos que han padecido el mismo tipo de maltratos o rechazo. ${ }^{10} \mathrm{En}$

${ }^{9} \mathrm{H}$. Gerald Pearson, La adolescencia y el conflicto de las generaciones, Siglo Veinte, Buenos Aires, 1970, pp. 91-99. Citado por Francisco A. Gómezjara, en la introducción de Las bandas en tiempos de crisis, Ediciones Nueva Sociología, México, 1987, p. 9.

${ }^{10}$ Esteban Mestre, op. cit., p. 424. 
este sentido hay todo un campo de investigación dentro de las ciencias sociales y la psicología dentro del cual los trabajos de Erikson ${ }^{11}$ mencionan que la creación de "pandillas impuestas o artificiales" organizadas por maestros o tutores externos facilitan y fomentan los mecanismos de integración social para aumentar el desarrollo social y escolar dadas las virtudes intrínsecas a la organización pandilleril —cohesión, ritos, reglas, competencia entre sí, etc.- Estas propuestas analíticas dan pauta a los trabajos de terapia grupal y dinámicas de grupo con los jóvenes, con un reconocimiento implícito de las virtudes que tienen las agrupaciones de jóvenes.

A pesar de este desarrollo conceptual aparentemente terso, en el que los jóvenes se reunían para socializar entre sí y para iniciar su proceso de integración a la sociedad adulta, llama la atención cómo a partir de la década de 1950 surge un auténtico estallido de nuevos estudios que empiezan a catalogar y a reconocer dentro de las pandillas sus aspectos negativos, capaces de transformarse en una auténtica amenaza social. Para Francisco Gómezjara, esto no significó que las ciencias sociales hayan descubierto "nuevas realidades" sino que en el fondo se trató más bien de un cambio de orientación respecto a las demandas de trabajos de este tipo por parte de los grupos de poder. ${ }^{12}$

Desde esta perspectiva analítica, en esos años ya no se requería estimular a los jóvenes sino más bien establecer mecanismos de control, o de plano de nulificación, de las experiencias de organización juvenil, sobre todo en los casos en que éstas empezaban a ser contestatarias, críticas o abiertamente opuestas al stablishment, o sea, cuando los jóvenes parecían ya no estar dispuestos a esperar dócilmente la llegada de su etapa adulta y demandaban cambios, reformas y nuevos pactos sociales en el mismo momento en que estaban reunidos, es decir, en su momento histórico y en su espacio vital.

En aquel entonces, el panorama político y social del mundo desarrollado había cambiado enormemente con la irrupción de las guerras — Segunda Guerra Mundial,

${ }^{11}$ Erik H. Erikson, Sociedad y adolescencia, Siglo XXI, México, 1985. 12 Gómezjara, op. cit., p. 10.
Corea, Argelia y después Vietnam—, con la masificación de los medios de comunicación — principalmente la televisión- y con ellos el consumo masivo de bienes y servicios, las modas, etc. Esto facilitó el inicio de una hibridación de los gustos y las culturas, unidos ahora por el consumismo, que paralelamente permitía la existencia de imágenes estereotipadas, aceptadas o rechazadas de acuerdo con el sector social que emitiera su juicio valorativo. Dentro de este tipo de manifestaciones algunas se empezaron a desarrollar públicamente y a asumirse como verdaderas pandillas, como bandas o colectivos interesados en transgredir el sistema, en mostrarse diferentes, en adquirir imágenes provocadoras que fueron de inmediato interpretadas por la sociedad como amenazantes $y$, al no seguir o romper con "las reglas del juego" establecidas, empezaron a ser catalogados dentro de los conceptos de "conductas irracionales", ominosas y peligrosas que debían ser controladas.

A partir de este momento la investigación social fue dirigiéndose más hacia la búsqueda de los elementos "antisociales" de las pandillas. En el libro Niños delincuentes: la cultura de la pandilla, de Albert Cohen, ${ }^{13}$ se presenta un listado con las primeras características negativas de las pandillas: violencia, negativismo, rechazo a lo establecido y anti utilitarismo. Estas reflexiones no buscaban las razones de actuar de los jóvenes y al contrario, favorecían una interpretación desde la perspectiva del sistema social: el rechazo a lo establecido dejaba de ser una característica de la "demanda de cambio" generacional, para empezar a ser interpretada como una reacción contraria a "lo que se debía esperar" de una juventud organizada y con un futuro promisorio dentro de la sociedad estadounidense. Esta posición se fue acentuando poco a poco con la participación de Estados Unidos en las diferentes guerras, olvidando un poco o dejando de lado que el comportamiento "agresivo" era innato al sistema y a la reproducción natural del capitalismo.

De esta forma, en el campo de la teoría renace el concepto de la anomia de Durkheim, tanto en su versión de

\footnotetext{
${ }^{13}$ Albert K. Cohen, Delinquent Boys: The Culture of the Gang, Free Press,
} Glencoe, Illinois, 1955. 
desorden y transgresión, como en la visión de Merton que habla de una deficiente integración entre la estructura cultural y la social. ${ }^{14} \mathrm{~A}$ partir de este momento se empieza a hablar de la "desviación social" como una forma de integrar en un solo concepto diversos fenómenos que antes se percibían de forma multidisciplinaria y por separado — derecho, medicina, psicología, antropología, ética, etc.- y que, finalmente unidos, podían llegar a considerarse entonces como "problemas sociales" que provocan o fomentan una desintegración social. ${ }^{15}$ Pero aún así, las problemáticas específicas relacionadas con la desviación social seguían interpretándose como casos aislados, excepciones a la regla, desequilibrios momentáneos, actitudes extraordinarias, posiciones exclusivas de un solo grupo, cuya explicación causal podía interpretarse desde la perspectiva social de la anomia o la deficiente integración social hasta algunas otras consideraciones fundamentadas en la biología o el psicoanálisis. ${ }^{16}$

Esto llevó al surgimiento de una serie de tipologías donde primero se definía al tipo de pandilla para luego ser estudiada como conducta desviada. ${ }^{17}$ Un caso curioso se presenta en los llamados países "socialistas", en donde las pandillas aparecen catalogadas como conductas criminales que deben ser incorporadas al campo de las sociopatologías. ${ }^{18}$ Los medios de comunicación tuvieron un impacto directo en la expansión y arraigamiento de este tipo de interpretaciones del fenómeno. "Para Horkheimer y Adorno, con el colapso de la familia como principal instancia socializadora, surgió la 'industria cultural', que apoyada en los medios de comunicación masiva devino en una estratégica agencia socializadora, cuya principal característica es la de tener una función mediatizadora, evidenciando así el carácter represivo y manipulador de

\footnotetext{
14 Robert Merton, Teoría y estructuras sociales, FCE, México, 1966. 15 Tamar Pitch, Teoría de la desviación social, Nueva Imagen, México, 1980.

${ }^{16}$ Gino Germani, Estudios sobre sociología y psicología social, Paidós, Buenos Aires, 1971.

17 Para profundizar la información en este sentido se recomienda revisar el libro Delincuentes juveniles y criminales de Don C. Gibbons, FCE, México, 1969.

${ }^{18}$ W. Mitter, "Criminalidad juvenil", en Marxismo y Democracia (serie Sociológica, núm. 3), Rioduero, Madrid, 1975, pp. 39-45.
}

los medios de comunicación masiva."19 Los medios de comunicación merecerían un estudio aparte en su relación con la creación y asimilación social de estereotipos... además de ser un jugoso negocio empresarial.

La exhibición en películas y programas televisivos de los jóvenes como violentos, pandilleros, ladrones o de plano criminales creó todo un nuevo mercado en el que la imagen de los jóvenes no sólo estaba destinada al público consumidor sino que, al mismo tiempo, fue una especie de escuela en la que se le mostraba a los jóvenes cómo debían vestir, comportarse y actuar para poder expresar abiertamente su "rechazo social", su rebeldía, su insatisfacción adolescente o su inconformidad con el sistema. "La juventud, es el divino tesoro de sexo, drogas y rocanrol que el cine no sólo convirtió en una receta de explotación barata en donde cabía prácticamente de todo: desde El salvaje (1954), Rebelde sin causa (1955), Semilla de maldad (1955), Nacidos para perder (1967), Easy Rider (1969), hasta Naranja mecánica (1971), Fiebre del sábado por la noche (1977), Los guerreros (1979) — que son considerados los "padres" de las bandas de la década de 1980 en la ciudad de México-, La ley de la calle (1981), El odio (1994) o Trainspoting (1996), y muchas más, lo que creó toda una mitología sobre una generación rebelde, por naturaleza ensimismada en sus conflictos generacionales y derrotada de antemano por sus vicios." ${ }^{20}$ Puede decirse que ya para el final de los años sesenta, la teoría de la desviación social había adquirido su carta de naturalización en las instituciones académicas y en las agencias gubernamentales encargadas de formular y aplicar las políticas de desarrollo social.

En el caso de México, parece oportuno señalar un cierto paralelismo entre los enfoques analíticos de la juventud y la formulación de la política gubernamental dedicada a la "atención de la juventud" (cuyos orígenes datan de la época cardenista, en 1939) y que podría resumirse en cuatro lineamientos básicos: 1) mantener a los jóvenes ocupados y entretenerlos creativamente (capacitación, promoción, uso del tiempo libre); 2) llevar un control social

${ }^{19}$ Héctor Castillo Berthier, Juventud, cultura y politica social, Instituto Mexicano de la Juventud, México, 2000, p. 31.

${ }^{20}$ Héctor Castillo Berthier, op. cit., 2000, p. 167. 


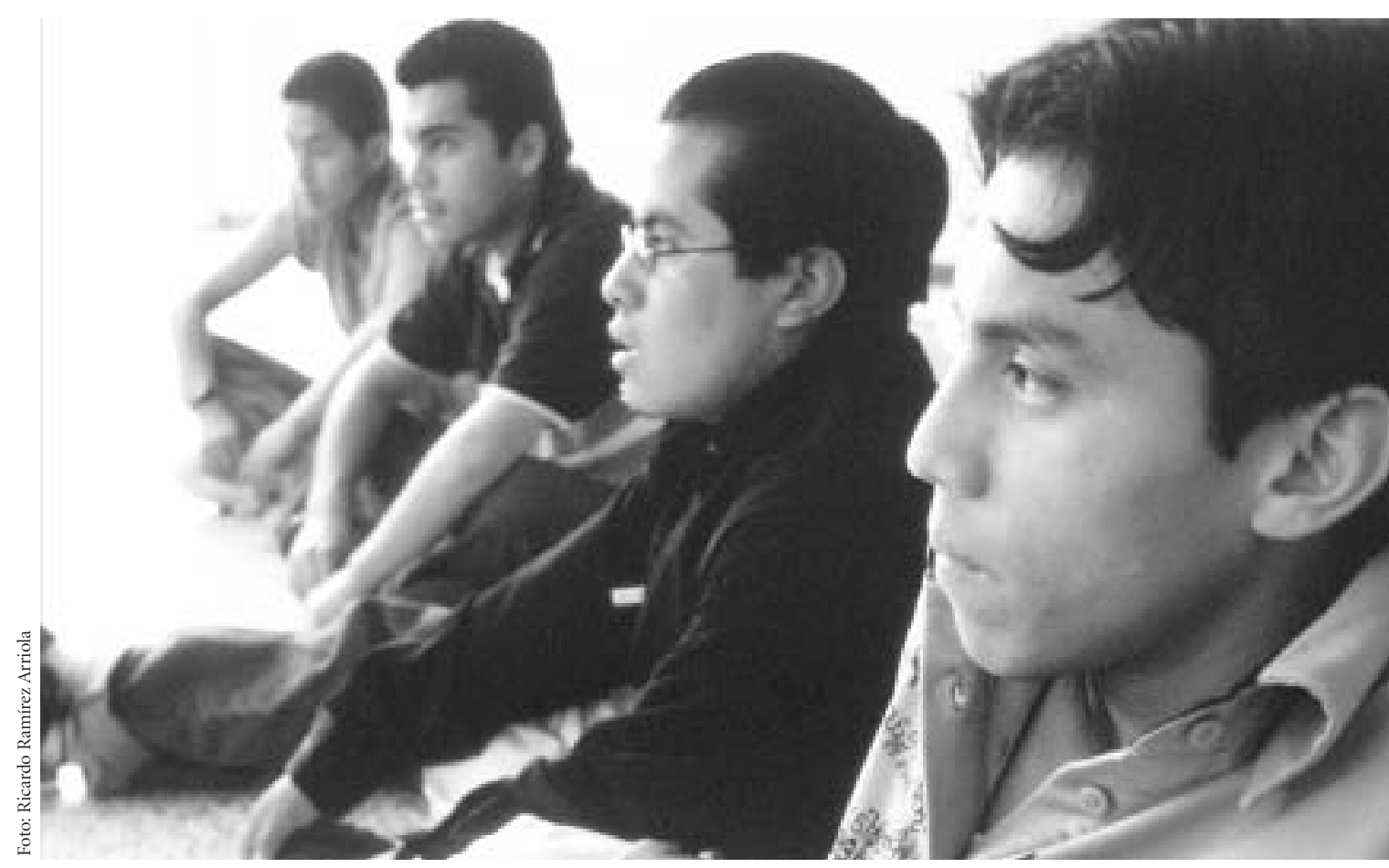

"Tenía cinco años cuando empecé a vivir en la calle. Me mantenía todo el día en la banqueta esperando que pasara alguien para robarle, para oler thiner."

de los jóvenes movilizados (cooptación de grupos de líderes de izquierda, guerrilleros, pandillas, bandas y todos los que representen un peligro real o potencial); 3) la captación política (incorporarlos al partido oficial y a la dirección política de diversos frentes y movimientos sociales); 4) la institucionalización de los apoyos (programas de combate a la pobreza, de inserción laboral para excluidos, de prevención del delito, contra la fármacodependencia, de educación abierta, etc.). ${ }^{21}$ Esto es, funcionalmente los jóvenes eran "controlables" si se les incorporaba en forma individual y se intentaba evitar la creación de agrupaciones de mayor alcance, sobre todo si éstas pretendían ser "independientes". Pero en realidad no se trata de un problema individual ya que "la vida colectiva

${ }^{21}$ Héctor Castillo Berthier, "Cultura y juventud popular en la ciudad de México", en Rafael Cordera, José Luis Victoria y Ricardo Becerra (coords.), México joven: politicas y propuestas para la discusión, UNAM, México, 1996, pp. 210-219. requiere certidumbre y, en particular, certidumbre precisamente acerca de lo colectivo".22

Todo esto permitió consolidar una idea más o menos clara y común en los países occidentales: las conductas anómicas juveniles correspondían a una visible y ostensible desviación social y el origen de la misma estaba en los individuos y en la familia, con lo cual, simultáneamente, se eliminaba casi por completo el derecho a la crítica, a la organización colectiva de "los desviados", al ejercicio de la libertad de asociación, para dejar la resolución de sus problemas en manos de las políticas asistenciales del Estado y de los especialistas.

La resistencia juvenil, tratada como desviación social, abarca tanto las manifestaciones de la clase media radical y a las pandillas influidas por el jipismo de los años sesentasetenta, como a las expresiones pandilleriles nacidas entre

22 Norbert Lechner, Los patios interiores de la democracia. Subjetividad y politica, FCE, Chile, 1990, p. 129. 


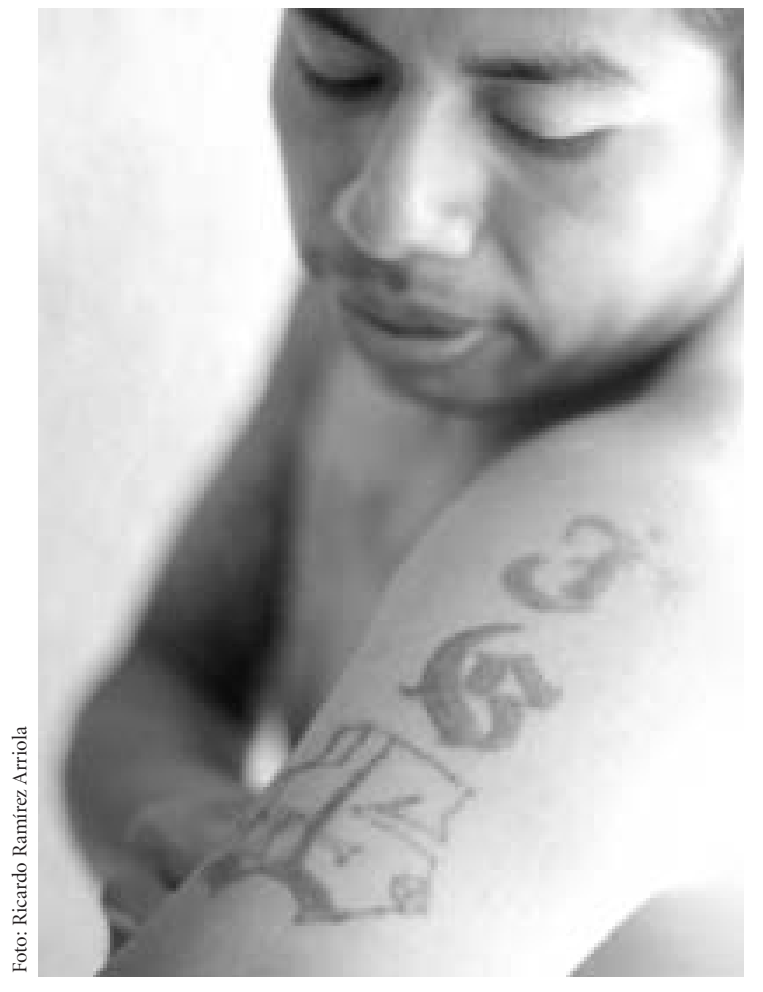

"Si no lo matás te matan. Es la ley de la supervivencia en la calle. Tienes que ver cómo sales adelante porque si no valés."

los jóvenes desocupados, subocupados u ocupados discriminativamente, asentados en las barriadas decadentes que ocupan el 50\% del territorio urbano. Desde esta perspectiva teórica, no se aspira a comprender el fenómeno juvenil sino a descalificarlo globalmente de antemano. Es así como las ciencias sociales oficiales juegan el doble papel de contenedoras de las manifestaciones críticas de los jóvenes y de justificadoras de las medidas de control social del Estado-empresa privada sobre esos mismos sujetos. ${ }^{23}$

Pero para principios de la década de 1970 el fenómeno de las pandillas y las bandas juveniles explota y empieza a aparecer lentamente en la vida cotidiana de prácticamente todas las ciudades del mundo, con una nueva generación de jóvenes rechazados o auto rechazados y auto devaluados, retando abiertamente al sistema, a sus símbolos, a las viejas creencias. Junto con estas agrupaciones

${ }^{23}$ Gómezjara, op. cit., 1987, p. 14. aparece toda una corriente de pensamiento descontenta con el papel conservador que habían venido construyendo las instituciones. Diversos autores señalan simbólicamente el año de 1968 como el punto de partida de esta corriente reformista, encargada de relativizar el valor de las normas legales al modificar la apariencia objetiva y científica del conocimiento, para introducir una propuesta mucho más abierta y libre que devolvía a los sujetos su papel como nuevos actores sociales y en la cual la revaloración cultural de los grupos empezó a desempeñar un papel determinante.

Un autor como C. W. Mills, ${ }^{24}$ considerado por muchos como el fundador de la sociología radical estadounidense, describía a los patólogos sociales como "guardafronteras del sistema capitalista” puesto que pretendían separar y apartar los factores económicos, políticos, sociales, culturales e históricos de los "desviados sociales", lo cual es un absurdo ya que, finalmente, estos elementos conforman el gran marco de referencia que le da cierto significado a esa desviación. Desde la psicología también se hicieron propuestas en este sentido, pero ciencias como la antipsiquiatría o la llamada psiquiatría democrática, han demostrado que el uso de muchos conceptos asociados a la locura ha servido para aislar y vigilar diversas manifestaciones de rechazo y desacuerdo social. ${ }^{25}$

De esta forma la descripción simplista de las pandillas y bandas juveniles como meros sujetos aislados, desadaptados, inmaduros o enfermos aparecía expuesta como un mecanismo de control ideológico del Estado y las clases dominantes. La aparición de visiones más abiertas, menos rígidas, ligadas a la interpretación histórica de los sujetos y al respeto de las identidades sociales ha permitido ampliar la visión que se ha tenido de estos grupos, e incluso ha favorecido su autopercepción como formas de resistencia y reagrupamiento civil para enfrentar una realidad opresora y poco comprensiva. Un ejemplo de ello es Foucault, ${ }^{26}$ quien despoja a la teoría criminológica de su pretendida racionalidad universal y exhibe clara-

${ }^{24}$ C. Wright Mills, Poder, política, pueblo, FCE, México, 1964.

25 Claudio Martín, El fin del manicomio, Nueva Sociología, México, 1985 .

26 Michel Foucault, Vigilar y castigar, Siglo XXI, México, 1980. 
mente su papel como controladora y supervisora del comportamiento de la sociedad. Dice Gómezjara:

Mientras en la esclavitud el que infringe la norma es convertido en esclavo, en el feudalismo es castigado físicamente porque el cuerpo es el bien más accesible dada la escasez de moneda y producción. Bajo el capitalismo el que viola la ley es creado, recreado, manejado y utilizado por el sistema. No es ajeno ni desviado. Por el contrario: es premeditadamente confeccionado para apuntalar el funcionamiento social en general. Sirve para que la población crea que es el origen de los males sociales: objeto sobre los cuales las clases populares vierten su hostilidad y desconfianza, dejando intacta la imagen del poder. Se utiliza para mantener el control de actividades públicamente ilegales pero económicamente muy redituables como el narcotráfico, la prostitución, el contrabando; aparece como proveedor de los cuerpos policiales y viceversa (policías-delincuentes). Justifica los grandes presupuestos policiaco militares y los proyectos de control personal (tarjeta de identidad, filiación de empleados públicos). ${ }^{27}$

Hoy estamos frente a una realidad indiscutible, los jóvenes cada vez más se agrupan alrededor de sus intereses colectivos: la cultura, sus creencias, sus imágenes contestatarias, su percepción auto devaluatoria, el uso del tiempo libre, el consumo o bien su rechazo a la globalización y al sistema en general, los cuales podrían ser apenas algunos ejemplos de las vías a través de las cuales la juventud contemporánea va conformando su actual identidad histórica. Pero paralelamente y frente al alarmante aumento de la delincuencia y la violencia social, hay otros jóvenes que se han ligado a la delincuencia y a los grupos criminales organizados - los sicarios colombianos, las maras de El Salvador, las pandillas de Los Ángeles, Nueva York o Chicago y muchos más—, cuya imagen no siempre se distingue de los otros y que sirve para recrear una percepción social negativa de los jóvenes en general, frenando su desarrollo generacional como actores estratégicos del cambio social.

Por ello y pese a todo, se deben distinguir claramente dos tipos de grupos juveniles, muy diferentes entre sí y con objetivos de vida diametralmente opuestos: las bandas o

${ }^{27}$ Francisco Gómezjara, op. cit., p. 16. tribus o colectivos - reunidos a partir de distintas interpretaciones culturales que generan y reproducen patrones visibles de comportamiento común-; y los pandilleros —que siempre han existido y que están directamente conectados a la delincuencia y al crimen organizado- que pueden jugar un papel determinante en la "contaminación" de otros jóvenes habitantes de sus barrios.

En entrevistas con jóvenes, con sus familias, con educadores y agrupaciones que trabajan en estrecho contacto con ellos se dan testimonios de la importación y adopción de la cultura del pandillerismo entre las bandas: su vestimenta, tatuajes, símbolos corporales, lenguajes, el graffiti, la música, cultura que va ligada a un creciente clima de inseguridad, de portación de armas, de delincuencia y de violencia, clima que los pandilleros generan y que acentúan en cambios significativos en el comportamiento de los menores en sus familias, en sus barrios y hasta en sus escuelas. Separarlos e identificarlos no es sencillo pero debería ser, sin duda, uno de los objetivos actuales de la investigación social a este respecto.

\section{VIOLENCIA: VÍCTIMASY VICTIMARIOS}

El mundo atraviesa por momentos muy crudos y la violencia es uno de los reflejos más dramáticos de los procesos de globalización. La violencia se ha convertido en un lugar común en nuestras sociedades y ésta se ha incrementado sin precedentes durante los últimos treinta años, en los cuales hemos sobrepasado su percepción frente a cualquier experiencia anterior de la humanidad. Una vez que el mundo se ha vuelto más pequeño, con el fin de la guerra fría, la caída del muro, la aparición de internet y el desplome de mitos e identidades impuestas a la fuerza, el hombre voltea la mirada sobre sí mismo y se descubre esclavo de sus propios errores.

Todas las formas de injusticia inimaginables, las guerras, la lucha por el poder económico, la impunidad, la corrupción, el terrorismo, el racismo, el hambre, la pobreza, la miseria extrema, aparecen cotidianamente en las noticias y, por consiguiente, en la construcción de la historia contemporánea a través del cine, la radio y la televisión, que se han erigido en los principales medios de 
educación, culturización y mediatización de los pueblos. La constante y permanente repetición de muchas y muy distintas situaciones de violencia en nuestra vida diaria nos ha desensibilizado ante lo que representa el dolor y el sufrimiento humano, ocultos detrás de una enorme máscara publicitaria que alienta la exhibición de programas bélicos y amarillistas.

Los efectos de esta pérdida de sensibilidad van acompañados de otros fenómenos de tipo económico estructural: los bajos salarios, el desempleo, la proliferación de la informalidad, el narcotráfico, las bajas tasas de crecimiento económico y la pérdida de confianza en las instituciones. Por ello no es exagerado decir que los orígenes de una gran parte de la violencia presente en nuestra sociedad se localizan en el pobre desarrollo económico de las ciudades, donde se concentra $75 \%$ de la población en América Latina.

Así, mientras los procesos de globalización de los mercados van ahondando cada vez más las diferencias entre los estratos sociales más ricos (pocos) y los más pobres (muchos), la violencia se va arraigando y multiplicando en las formas más insospechadas, principalmente entre los jóvenes, que la reciben como enseñanza diaria y en forma natural, ante la aparente modificación de los valores tradicionales que se tenían respecto a la vida, al trabajo, a la familia y a la sociedad en su conjunto. El dinero se ha convertido en el valor esencial de nuestra sociedad y no tener acceso a él, o tener un acceso muy limitado, propicia el aislamiento, la frustración, la exclusión y la soledad.

Es justamente en esta perspectiva económico-emocional donde podemos encontrar una de las fuentes principales por las que se desarrolla el creciente clima de violencia. La desvalorización de la sociedad familiar defrauda a muchos jóvenes ante la ausencia, en numerosos casos, de un ambiente feliz al cual justificadamente sienten que tienen derecho. Los jóvenes toman sus propias decisiones, pero claramente están influidos por aquellos con quienes se relacionan y así, mientras para algunos la base de relación es la familia, un club deportivo o la escuela, para otros sólo está la calle, la esquina, la pandilla, el ghetto, o sea, el inframundo de la exclusión social.

Ya es mucho lo que se ha escrito sobre el comportamiento de los jóvenes desde muy distintas disciplinas, sin embargo, para contextualizar a este grupo en especial, suponemos en un principio que "en el interior del universo social y territorial de las clases populares, su juventud ha adquirido nuevos modos de vida y nuevas expresiones en varios niveles. La escuela, institución que con anterioridad generaba expectativas de movilidad social ascendente demuestra hoy, en los hechos, una limitada capacidad para lograr este objetivo. El mundo del trabajo, por su parte, ya no ofrece un amplio abanico de opciones ocupacionales sino que, por el contrario, presenta fuertes barreras para que un joven con escasa o nula calificación manual u ocupacional dispute un lugar en un mercado restringido por las crisis recurrentes. Por su parte, la cultura, los valores, los comportamientos tradicionales de la sociedad ya no son los suyos, ya no los incorporan tal como lo hicieron las generaciones anteriores. La familia parece debilitarse frente a la imposibilidad de ofrecer a sus miembros jóvenes un espacio de socialización primaria fuerte, contenedor, capaz de orientar, como lo hizo tradicionalmente, una de las etapas más difíciles del ser humano: la juventud". 28

Los jóvenes que crecen en familias donde hay abusos y maltrato, o bien sufren de los diferentes comportamientos violentos de sus seres más allegados, aprenden desde pequeños a responder en la misma forma cuando tienen que enfrentar alguna situación de enojo o frustración. Pero aquellos que nacen ya de por sí en condiciones económicas adversas, enfrentan desde el inicio de sus vidas una doble lucha: primero contra la pobreza y su medio ambiente, y después contra una sociedad que no ha acabado de establecer reglas claras y un estado de derecho que faciliten y apoyen el desarrollo y la igualdad de los individuos.

La violencia existe con distintos niveles en todos los países del mundo, es una condición humana de la que no se puede huir ni esconder, y se presenta de muy diversas formas y con particularidades muy concretas. Así, podemos encontrar muchos tipos de violencia. Lo que en ciertos países puede ser considerado como "normal" — desde las

\footnotetext{
${ }^{28}$ Héctor Castillo Berthier, "De las bandas a las tribus urbanas", Desa-
} catos, núm. 9, CIESAS, México, 2002, p. 58. 


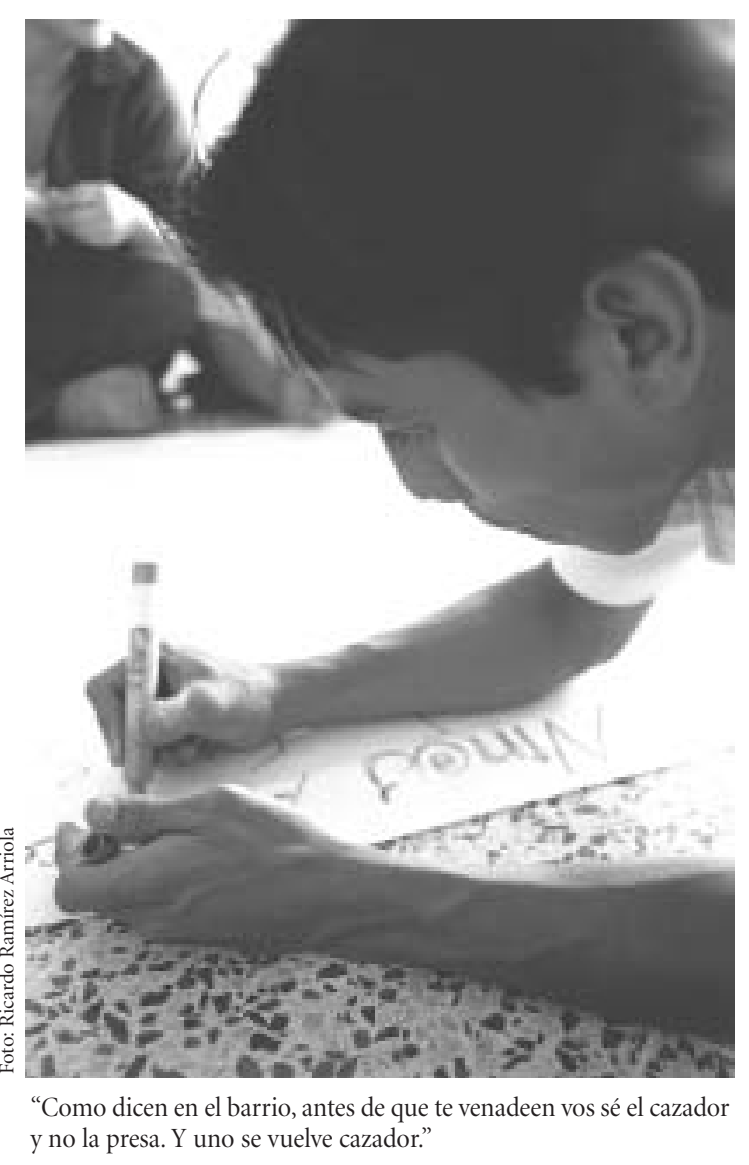

peleas de gallos, las corridas de toros, la lapidación, la pena de muerte, el derecho a la venganza o la muerte por inanición - en otros, esas manifestaciones son temas de verdadero escándalo.

Sin embargo, la violencia es innata al ser humano y el hombre, en su primitivismo, ha utilizado la violencia para todo: para conquistar territorio, defenderlo, ganar dinero, imponer una ideología, obtener prestigio y poder, y después de esta cuantiosísima inversión de violencia, hoy se desenvuelve en un mundo cada vez más devastado, donde la geografía impuesta parece desmoronarse poco a poco, dando pie a nuevas luchas, cada vez más violentas. Pero hay otros tipos de violencia, como aquella que resulta de las apremiantes necesidades económicas de la población, o del fanatismo religioso, o de la búsqueda de identidad por la sentida destrucción de los valores cul- turales y tradiciones de algún grupo social o de una etnia. Entre todos estos tipos, hay uno en especial que gira alrededor del fantasma de los llamados "barrios bajos", empotrados en ciudades perdidas, en callampas, en los tugurios marginales de las periferias urbanas y en el cual la pobreza aparece a cada paso. El mundo actual presenta una estadística brutal: $80 \%$ de la población mundial es pobre y un alto porcentaje de ésta vive en condiciones de extrema pobreza.

El hambre provoca ira, sin duda, y la miseria de los pueblos exacerba esta situación. Cada día mueren cientos y miles de personas en riñas callejeras, asaltos y violaciones, principalmente hombres y mujeres de las zonas marginales. Pero esto, de ser tan cotidiano, casi pasa desapercibido, como si estuviera lo suficientemente "lejos" de nuestras vidas. Se dice que es lógico que las situaciones de violencia se agraven con la pobreza, y que los jefes de familia que se encuentran sin haber terminado siquiera la escuela primaria, desempleados, o que viven "de milagro" gracias a la informalidad económica, sean más propensos a tener hijos delincuentes, pero ésta es sólo una de las caras del problema. Entre los distintos tipos de violencia que pueden generarse en las sociedades existen verdaderos abismos que separan una lógica de otra: está la violencia como forma de protesta, como mecanismo de defensa, la violencia exhibicionista, la política y muchas más, lo cierto es que dentro de este clima violento, los jóvenes ocupan un lugar sobresaliente en las estadísticas oficiales y en la imagen que se presenta de ellos en los medios masivos de comunicación.

Se dice que la violencia juvenil expresada en la delincuencia es una de las formas de violencia más evidente en la sociedad. "A escala mundial, los medios de comunicación, sean impresos o electrónicos, a diario nos dan cuenta sobre la violencia en jóvenes que se manifiesta de la más variada forma, ya sea en la calle, en la escuela o dentro del propio hogar. En casi todos los países, los adolescentes y los adultos jóvenes son tanto las principales víctimas como los principales generadores de la delincuencia." 29

29 René Jiménez Ornelas, Delincuencia juvenil y prevención, IISUNAM, México, 2003, mimeógrafo. 


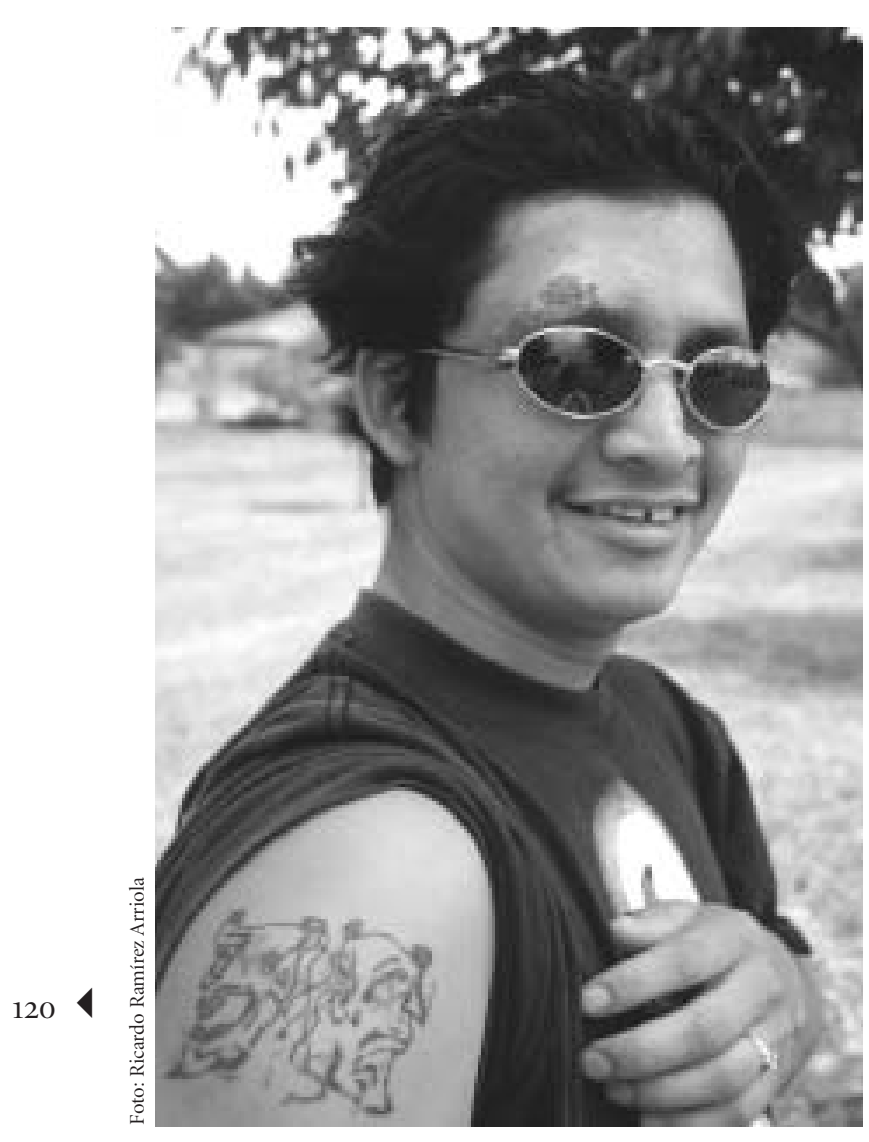

"Ahorita Nelson trabaja, estudia educación popular y en la noche está terminando su primaria."

La Encuesta Nacional de Inseguridad realizada por el Instituto Ciudadano de Estudios Sobre la Inseguridad (ICESI) en el $2002^{30}$ mostró que $54.3 \%$ de los delincuentes cuenta entre 16 y 25 años de edad, es decir, que más de la mitad de los delincuentes son jóvenes. Solamente 3\% son niños menores de 15 años. Estos datos demuestran que los jóvenes recurren a la delincuencia, siendo el robo o el asalto el delito en que más incurren $(58.2 \%$ de los casos), utilizando para la perpetración del hecho delictivo navaja o cuchillo en la mayoría de los casos.

\footnotetext{
${ }^{30}$ ICESI, Encuesta nacional sobre la inseguridad, México, 2002, llevada a cabo del 2 al 24 de marzo de 2002, con un nivel de confianza de $95 \%$ y un margen de error de $+/-1 \%$, cuenta con representatividad nacional y estatal con 35001 cuestionarios realizados.
}

Los jóvenes de los sectores populares en México son víctimas de un modelo social que conduce a la violencia, no sólo por los estigmas tradicionales que ligan a los jóvenes con la violencia, la delincuencia, el consumo de drogas y el alcohol ("se estima que en nuestro país hay 3 millones 241 mil consumidores de alcohol, cigarro y drogas ilícitas"), 31 sino también al influir otros elementos valorativos presentes de muy diversas formas: el odio, el sentimiento de olvido y abandono, el rechazo, el resentimiento social, la venganza y muchos más que parten del sentimiento de los jóvenes hacia la sociedad —y muy particularmente hacia las instituciones-, como de éstas hacia los jóvenes. Por ello, no se debe olvidar el verdadero origen que tiene esta situación y que no es otro que la conformación histórica del sistema político, económico y social, en el cual los jóvenes han desempeñado y desempeñan actualmente un papel muy secundario y de muy bajo perfil.

Diversos especialistas en la atención a los jóvenes coinciden en que la principal causa que permite explicar la delincuencia juvenil tiene que ver con los bajos niveles de la calidad de vida en México. Si se hiciera una comparación entre las estrategias y políticas públicas desarrolladas de manera permanente para los jóvenes en los países industrializados, frente a los magros avances de las políticas nacionales para la juventud, podríamos entender por qué, en una encuesta reciente realizada por el Instituto Nacional de la Juventud, más de 90\% de los jóvenes entrevistados en todo el país dijeron no saber o conocer muy superficialmente la existencia de dicho instituto y mucho menos estar enterados de las actividades que desarrolla.

Como comenta la doctora Elena Azaola, consejera de la Comisión de Derechos Humanos del D. F.: "Qué se puede esperar de un país donde sólo 17\% de los jóvenes puede acceder a la universidad, de una ciudad en la que $24 \%$ de la población joven no estudia ni trabaja." Sostiene que desde 1995, la juventud mexicana no tiene más referentes que la crisis económica, la corrupción, la vio-

\footnotetext{
${ }^{31}$ Ramón Sevilla, "Engancha crimen organizado a tres de cada 100 menores", Reforma, 6 de noviembre de 2003.
} 
lencia, los crímenes, y si a eso se agrega el desgaste del tejido social o la patología de los vínculos sociales, la situación resulta peor. "De verdad, es grave, terrible, la pérdida de calidad de vida en el país." 32

Por otro lado, la participación de adolescentes y jóvenes se ha vuelto muy importante para el éxito o fracaso de ciertas operaciones delictivas, prueba de ello es que 3\% de los menores que viven en las principales ciudades del país están unidos al crimen organizado, como el robo de vehículos, asaltos, prostitución infantil, etc., organizándose en bandas o pandillas. ${ }^{33}$ Por ejemplo, en la ciudad de México se dice que existen alrededor de 351 "pandillas de delincuentes", muchas de las cuales han incorporado a sus filas menores de edad, adolescentes y jóvenes, ${ }^{34}$ a lo cual habría que contraponer un dato significativo y esperanzador: en 1988, en el Diagnóstico de bandas, realizado en el Instituto de Investigaciones Sociales de la UNAM, se hablaba de la presencia de poco más de 1500 "bandas de jóvenes" que se agrupaban en torno a su cultura y al uso colectivo de su tiempo libre sin que necesariamente estuvieran ligadas a la delincuencia. ${ }^{35}$

Aquí hay que hacer una acotación importante sobre un problema que llegó a ser muy frecuente durante el apogeo del fenómeno de los llamados "chavos banda" en la década de 1980, y es que el Código penal federal establece en su libro II, título IV, referido a los delitos contra la seguridad pública, en su capítulo IV: "Asociaciones delictuosas", y específicamente en el artículo 164, que será delincuente "[el] que forme parte de una asociación o banda de tres o más personas con propósito de delinquir, y se le impondrá prisión de cinco a diez años y de cien a trescientos días de multa...”, y, un poco más adelante, en el artículo 164bis explica: "Cuando se cometa algún delito por pandilla, se aplicará a los que intervengan en su comisión hasta una mitad más de las penas que les correspondan

32 E. Azaola, Proceso, 9 de mayo de 2002, citado por René Jiménez, op. cit., 2003.

${ }^{33}$ Ramón Sevilla, op. cit.

${ }^{34}$ Mónica Archundia, "Sobreviven en la ciudad 351 pandillas juveniles", El Universal, 9 de octubre de 2002.

${ }^{35}$ Héctor Castillo Berthier, Sergio Zermeño y Alicia Ziccardi, "Juventud popular y bandas en la ciudad de México”, Presencia, núm. 14, Río de Janeiro, 1989. por el o los delitos cometidos... Se entiende por pandilla, para los efectos de esta disposición, la reunión habitual, ocasional o transitoria, de tres o más personas que sin estar organizadas con fines delictuosos, cometen en común algún delito..."36

Y esto resultó ser muy significativo, ya que la diferencia semántica que hacían los policías - fundamentándose en el Código penal, que define: "banda" (delincuentes) y "pandilla” (grupos de reunión habitual, ocasional o transitoria... sin estar organizados con fines delictuosos)—, eran entendidos exactamente de manera opuesta entre los jóvenes (banda es recreación; pandilla es delincuencia), por lo que al momento de ser detenidos por la policía y decir que "estaban con su banda" eran de inmediato remitidos a los juzgados por "asociación delictuosa", aunque - hay que aclararlo- ésta sólo era una estrategia cotidiana que servía para extorsionar con mayores cantidades de dinero a estos jóvenes y a sus pobres familias.

A pesar de que el sistema penal en México no es eficiente y que se sabe de la existencia de una "cifra negra" que revela que la mayoría de los delitos no son nunca denunciados, las cifras existentes demuestran que la mayor parte de los delincuentes consignados son jóvenes. En este sentido, la Encuesta nacional sobre inseguridad mostró también que 37.6\% de las víctimas reportó el delito, de este porcentaje, $77.5 \%$ levantó un acta ante el Ministerio Público y sólo en 13.3\% de los casos se consignó al delincuente. De estos casos consignados $53.7 \%$ eran jóvenes de 16 a 25 años. ${ }^{37}$

En este mismo sentido, una investigación periodística publicada por la revista Proceso ${ }^{38}$ revela que $60 \%$ de la población penitenciaria sentenciada en los centros de reclusión del Distrito Federal es catalogada como joven, con un rango de edad de entre 15 y 29 años, y que los 134 centros de readaptación social juveniles en el país (correccional, tutelar y centros de diagnóstico) tenían una población de 2879 menores de 18 años reportados hasta

\footnotetext{
${ }^{36}$ Instituto de Investigaciones Jurídicas, Código penal federal, UNAM, México, 2004.

${ }^{37}$ ICESI, op. cit., 2002.

${ }^{38}$ Raúl Monge, "Juventud delincuente, explosivo crecimiento", Proceso, núm. 1331, 9 de mayo de 2002, pp. 4-8.
} 
el año 2001. En estos sitios, la problemática de los jóvenes se complica, ya que los centros de readaptación social se han transformado en auténticas escuelas del crimen, donde los adolescentes consignados por un delito menor aprenden nuevas estrategias para delinquir, con lo cual aumenta su riesgo de reincidir con delitos mayores.

Al tratar a la delincuencia como uno de los puntos más importantes relacionados con la violencia juvenil, es fácil darse cuenta del rumbo que puede tomar esta problemática si no se establecen medidas de contención. Por ello, la primera medida en este sentido debería ser la apertura de nuevos espacios de interacción y trabajo "con" los jóvenes —no "para" o "de" los jóvenes — que permitan empezar a generar una confianza hoy prácticamente inexistente. En la primera Encuesta nacional de la juventud realizada en 2000, 89.5\% de los jóvenes confesó no tener ningún tipo de confianza en los políticos. Pero en esos mismos datos aparece que sí tienen confianza en los maestros, los padres de familia, los amigos, por lo cual no se trata de una puerta totalmente cerrada o de un abismo insalvable. La segunda prevención debería ser el fortalecer su autoestima y destacar la importancia de su participación ciudadana, para que se perciban a sí mismos como actores estratégicos y protagonistas de su proceso de desarrollo. Si bien es cierto que los jóvenes tienen la fortaleza y energía para violentar, también lo es que en su mayoría desean ser útiles, experimentar con nuevas cosas y tener una visibilidad que les permita ser reconocidos por los otros individuos. Todo ello apunta a un objetivo común: enfrentar los estigmas que han propiciado su exclusión y que los transforman en víctimas y victimarios simultáneamente.

La sociedad de la exclusión se ha venido apoderando de nuestras ciudades y está cada vez más presente en nuestras vidas. Los efectos de la inconmensurable brecha económica existente entre ricos y pobres puede verse en todas las sociedades del Tercer Mundo. Los países así catalogados atraviesan por una crisis recurrente que mantiene separados a los segmentos sociales igual que el agua y el aceite. El futuro de las ciudades es ciertamente previsible si se le mira a través de la violencia: tendremos una activa sociedad de consumo, organizada alrededor de las grandes firmas corporativas, con una clase media pujante, aunque reducida, encargada de su funcionamiento y que guardará celosamente las únicas esperanzas y expectativas posibles para continuar la vida en las ciudades. Del otro lado, en los cinturones de miseria, habrá legiones de desempleados y subempleados, huérfanos de la modernidad y herederos perpetuos de las crisis económicas, enfrentando día con día la violencia que representa el sobrevivir a toda costa.

Los niños y jóvenes representan el futuro de la sociedad como se le quiera ver. Serán ellos la mano de obra, los encargados de ofrecer los servicios, los consumidores, los políticos, la fuerza de la economía y en ellos se concentra la única esperanza posible de cambio y modificación de los lastres que arrastra nuestra maltrecha realidad. Pero, al menos hasta este momento, no parecen incluir en su horizonte esa amplia gama de posibilidades que permitió a otras generaciones mejorar sus condiciones de vida y trabajo y, por el contrario, los jóvenes de los sectores populares parecen estar más lejos del concepto de desarrollo social que de poder desempeñar un papel predominante en el porvenir.

En la perspectiva de la administración pública — cuyo objetivo central declarado es la búsqueda de la felicidad colectiva-, la meta principal respecto a la violencia debe girar en torno a la clara identificación, desmitificación y reorientación de lo que se ha denominado como "factores de riesgo", ya que mientras el impulso destructivo básico de la rebeldía de los jóvenes permanece intacto, los métodos de expresión de esa rebeldía y las deterioradas condiciones de su entorno son hoy más peligrosas. Actualmente una pistola dice más sobre esta rebeldía de lo que pudo haber dicho el pelo largo, un arete en la nariz o un tatuaje hace apenas unos años. De ahí la necesidad de realizar esfuerzos multi y transdisciplinarios, que involucren en su concepción y puesta en práctica a los propios actores sociales, a los jóvenes. Dichos esfuerzos deben concentrarse justamente en atenuar los factores de riesgo — venganza, impunidad, búsqueda de la identidad extraviada, desesperanza, consumo y tráfico de drogas, entre muchos otros - pero, sobre todo, debe combatirse seriamente la pobreza y la miseria extrema. Por ello, los programas de atención y prevención de la exclusión social deben empezar desde las edades más tempranas de 


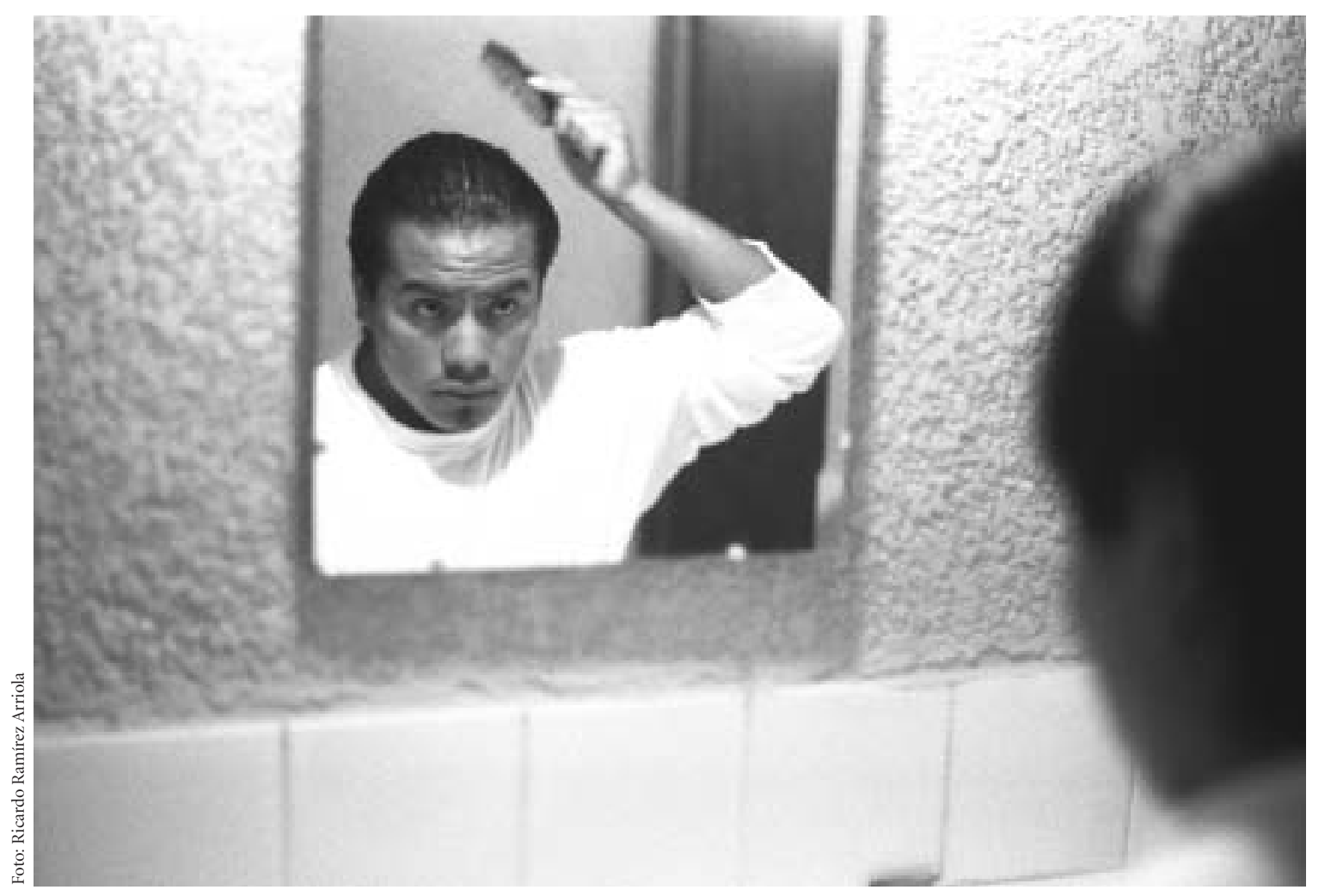

"Yo no soy un profesional de los estudios pero puedo enseñar. Manejamos obras de teatro. En agosto de este año vamos a dar una capacitación a 200 maestros."

los sujetos, incluso desde antes de que se inicie la educación elemental, ya que esperar hasta la adolescencia o hacerlos accesibles solamente a partir de la juventud puede resultar en muchas ocasiones en una acción tardía.

\section{¿A DÓNDE VAMOS?}

Ya se han mencionado las distintas percepciones que se tienen de los jóvenes, de sus estigmas, de esa permanente idea de etiquetarlos negativamente y del papel que han desempeñado los medios de comunicación para la construcción de estas imágenes perversas. También quedó claro que no todos los jóvenes tienen una actitud positiva y de superación ante la vida. Aquí no hay absolutos ni puede agruparse bajo un mismo color el complejo espectro de grupos que conforman el concepto "juventud".
Los jóvenes de los sectores populares, las bandas, las pandillas, han pasado de ser englobados por los conceptos invisibles de la academia a ser reconocidos en las imágenes ostensibles de los medios, y muchas perspectivas "antisociales" siguen permeando el ambiente en forma creciente. Un graffiti textual de la ciudad de Tijuana hace algunos meses indicaba: "Yo no soy anti-sociedad; la sociedad es anti-yo." Existe ciertamente un sentimiento de indefensión — que no es privativo de los jóvenes-, una realidad cotidiana de todos los ciudadanos frente a los gobiernos, a la impunidad política, a sus fracasos para disminuir la delincuencia y la inseguridad, frente a un clima de violencia expansivo con orígenes diversos, lo cual desemboca en la demanda de acciones puntuales — también visibles—, reflejadas en los operativos de control y medidas policíacas, principalmente en los barrios populares. 
Se trata de "un discurso que engendra su propio orden y que se ofrece a sí mismo como discurso de la certidumbre y que se alimenta precisamente del miedo [al otro especialmente], de la duda y contribuye a erosionar el vínculo social... [por ello habría que] reflexionar en torno a los mecanismos que han convertido a los jóvenes [especialmente de los sectores populares] en los destinatarios del autoritarismo que tiende a fijar en ellos, de manera obsesiva, los miedos, las incomprensiones, las inquietudes que provoca hoy la vulnerabilidad extrema de la sociedad en diversos órdenes". ${ }^{39}$ ¿Existe alguna forma de promover una mejor comprensión de los jóvenes?, ¿quiénes serían los responsables de esto?, o acaso ¿no lo somos todos?

A pesar de la caótica situación existente es preciso mencionar un dato importante: así como se dice que los jóvenes delincuentes son minoritarios frente al espectro global de la juventud, de la misma manera las pandillas también lo son — socialmente hablando- - Sin embargo, el contexto de esta ventaja relativa está inmerso en un entorno de alta peligrosidad que puede quebrantar con

cierta facilidad a los jóvenes no pandilleros o no delincuentes, vecinos directos de las zonas consideradas de alta peligrosidad. Entre ellas, y sólo para citar algunas de las más visibles, están: el elevado número de familias pobres, las condiciones de infra subsistencia, la falta de proyectos de nación a largo plazo, la ausencia de una planeación estratégica frente al futuro previsible, la inexistencia de espacios de socialización y recreación de los jóvenes fuera de la escuela, los estigmas negativos diseminados y machacados por los medios de comunicación, el surgimiento de un discurso autoritario que demanda un mayor control de los gobiernos y que clama por las "operaciones de limpieza", el incremento de la marginalidad y la exclusión social, la desintegración familiar, el abandono escolar, la falta de empleo, la pérdida de credibilidad en las instituciones y la penetración de la delincuencia organizada en los grupos juveniles. Existen barrios donde la violencia es una forma de vida y los residentes tienen que

${ }^{39}$ Rossana Reguillo, La construcción del enemigo, Iteso, México, 2003, mimeógrafo. adoptar esa actitud, si es que desean ser tratados con respeto y no permanecer como simples víctimas, es decir: combatir violencia con violencia.

En México existen actualmente alrededor de 30 millones de jóvenes con edades que fluctúan entre los 12 y los 29 años, y que representan cerca de 30\% de la población total del país. Sin embargo, y a pesar de la magnitud numérica, la política, o mejor dicho, las políticas públicas y privadas que se aplican para su atención hasta la fecha han tenido una vida fortuita y aventurada y no han logrado integrarse a las demandas que impone la realidad. Por ejemplo, si partimos de la premisa que el desempleo juvenil es igual al del resto de la economía, y que por ende, si se resuelve el problema del desempleo se resuelve el del desempleo juvenil, partimos de una premisa falsa, ya que el desempleo juvenil es un fenómeno estructural en el que, además del empleo en sí mismo, la edad, la falta de experiencia, la capacitación y la calificación de la mano de obra sólo sirven para apoyar a los jóvenes más integrados, dejando fuera casi automáticamente a la mayoría juvenil popular.

Por lo antes dicho es importante diferenciar las problemáticas existentes en el mundo juvenil. La exclusión se da en el campo de la educación porque hay una incorporación segmentada, relacionada directamente con el tipo de servicios educativos que el joven haya adquirido, su grupo de interacción cotidiana y, por consiguiente, con su origen social. La propia lógica educativa actual resulta de un modelo pensado para jóvenes integrados, con una base familiar estable; es por ello que creemos que para los jóvenes excluidos de los sectores populares resulta indispensable pensar y trabajar en sus formas de integración a partir de sus experiencias vitales.

En otro terreno, podríamos decir que los jóvenes también se encuentran excluidos del campo de la salud porque, como lo dicen los propios médicos, "son los que menos se enferman", dando prioridad a la atención de los más vulnerables. Los sistemas actuales de salud pública parecen estar pensados sobre todo para adultos, favoreciendo programas de combate a las enfermedades (cólera, difteria, tos ferina, tétanos, etc.) que programas de prevención y promoción de estilos saludables de vida. 
En lo tocante a la vivienda, por ejemplo, todas las políticas están pensadas para que el individuo que quiera tener acceso a un lugar donde vivir esté incorporado previamente al sistema laboral, por eso los jóvenes, generalmente, sólo tienen acceso a algún tipo de vivienda cuando se proponen formar una pareja y trabajar, generalmente cuando ya no se consideran jóvenes. Pero éstos, como grupo social, necesitan de programas de salud preventiva, capacitación laboral, educación, empleo y algún tipo de vivienda, sin embargo, en muchos casos son excluidos, y esto hay que subrayarlo: actualmente la exclusión juvenil no es un tema de la agenda pública. Los jóvenes no deben verse sólo como usuarios, beneficiarios o simples destinatarios pasivos o receptores de la política, sino que deben ampliarse sus habilidades, sus potencialidades, deseos y necesidades con el objeto de transformarlos en actores reales de su propio desarrollo.

La juventud de los sectores populares se desenvuelve en un medio caracterizado por la falta de oportunidades de empleo; a pesar de ello, la cultura alternativa que genera "en la esquina", en sus reuniones informales, en el barrio, sirve como producto generador de identidad, y crea medios diversos para expresar sus ideas, preocupaciones, sentimientos, emociones, etc. El joven urbano popular lo mismo lee una revista de modas o deportes que se preocupa por temas políticos y sociales. Si se revisan con cuidado estos productos, se encuentra una fuerte carga de valores: honestidad, respeto, amistad, confianza en la familia, pero sobre todo en sí mismo, que se ven reflejados en la cotidianidad de su producción cultural. Al joven urbano popular le preocupa tanto la contaminación como la inseguridad de su ciudad, lugar con el que establece una intensa relación de atracción y rechazo a la vez. Por ello, ahí en el seno de estos sectores se deben valorizar sus formas de expresión, ya que estas colaboran para que, tanto los propios jóvenes como el resto de la sociedad, reconozcan que son capaces de contribuir y de construir soluciones viables para los conflictos sociales y la violencia.

Se trata, en suma, de articular las múltiples experiencias locales basadas en principios comunes, en valores, en respeto a las identidades colectivas. Pensamos, por ejemplo, en los campesinos migrantes a Estados Unidos que encontraron en ese país una mejor alternativa de vida. Sus hijos y nietos nacieron allá, se educaron y se formaron de acuerdo con un determinado entorno económico y social que, en muchos casos, les fue dando cierta identidad, que los catalogó como "pachuchos", "chicanos", "cholos", asumiendo con ello toda una serie de características (lenguaje, vestido, formas de actuar, etc.) y estigmas (drogas, armas, tatuajes, etc.), y que al regresar o venir de visita a México, a sus pequeñas comunidades rurales, traen consigo toda esa gama de actitudes y valores que los hacen integrarse de una manera deforme y muchas veces maligna con su comunidad local. ¿`No merece la sociedad local de sus comunidades conocer abiertamente el significado de estas nuevas expresiones?, ¿no se puede pensar en espacios estructurados donde trabajar organizadamente con estos grupos?, ¿no es posible conjugar los conceptos juventud y cultura con la definición de una política social pública que prevea estos escenarios? Esa respuesta es justamente la propuesta final de este trabajo.

Vivimos actualmente en sociedades permeadas sistemáticamente por la información (a todos los niveles) y la seducción del consumo, en donde la lógica del capital, para obtener lucro o plusvalía, produce infinidad de mercancías con una obsolescencia programada que no sólo desecha productos, sino que desecha también personas. Los jóvenes de México nacen y crecen en medios muy diferentes, con posibilidades de éxito o fracaso señaladas de antemano, casi desde el momento de nacer. Los jóvenes llevan marcados en la frente, por así decirlo, su raza, origen y condición social, por lo que algunas veces puede adivinarse sin muchas dificultades su futuro.

Hoy en día la sociedad mexicana es más desigual que antes, más heterogénea, cuenta con una riqueza más concentrada y una población más excluida. En las ciudades y el campo hallamos por todos lados mundos distanciados por situaciones sociales tan disímiles como las que separan a Ginebra de Calcuta. Hoy la miseria más extrema está en las grandes ciudades, muy cerca del corazón de los centros financieros: ahí están los indigentes, los niños de la calle, las Marías, los vendechicles, los limpiavidrios, los payasitos, los ambulantes, los separadores de basura y alimentos, hombres y niños y jóvenes que no son realmente "otra sociedad" coexistiendo en el mismo país, 
sino la cara deforme de una misma moneda, el reverso real de nuestra modernidad. ¿Cuál puede ser el futuro de los jóvenes de los sectores populares en esta situación?

Las generaciones actuales recibimos un país por construir y hay problemas específicos a resolver, como serían las relaciones juventud-escuela, juventud-familia, juventud-instituciones, juventud-empleo, juventud-medios, juventud-delincuencia, etcétera. Debemos reforzar las redes de integración social y apoyar la reconstrucción valorativa de los distintos segmentos sociales, frenar la destrucción psicológica del individuo, recuperar la confianza, fortalecer la autogestión y la autoestima. Aún quedan muchas cosas que aprender de los jóvenes y de su realidad, por eso es tarea fundamental de toda la sociedad llevar a cabo acciones que garanticen su continuidad y su sano desarrollo, libre de violencia, delincuencia y desigualdad.

\section{Bibliografía}

Archundia, Mónica, 2002, "Sobreviven en la ciudad 351 pandillas juveniles", El Universal, 9 de octubre.

Asbury, Herbert, 1927, Gangs of New York, Garden City Publishing Company, Nueva York.

Bauleo, Armando, 1974, Ideología, grupo y familia, Folios, México.

Becker, Howard, 1971, Los extraños: sociología de la desviación, TC, Buenos Aires.

Bergalli, Roberto, 1983, El pensamiento criminológico, Península, Barcelona.

Castillo Berthier, Héctor, 1996, "Cultura y juventud popular en la ciudad de México", en Rafael Cordera, José Luis Victoria y Ricardo Becerra (coords.), México joven: políticas y propuestas para la discusión, UNAM, México, pp. 210-219.

—-, 2000, Juventud, cultura y política social, Instituto Mexicano de la Juventud, México.

_ 2002, "De las bandas a las tribus urbanas", Desacatos, núm. 9, CIESAS, México, pp. 57-71.

—_ Sergio Zermeño y Alicia Ziccardi, 1989, "Juventud popular y bandas en la ciudad de México", Presencia, núm. 14, Río de Janeiro.

Cohen, Albert K., 1955, Delinquent Boys: The Culture of the Gang, Free Press, Illinois.

Foucault, Michel, 1980, Vigilar y castigar, Siglo XXI, México. Erikson, Erik H., 1985, Sociedad y adolescencia, Siglo XXI, México.
Germani, Gino, 1971, Estudios sobre sociología y psicología social, Paidós, Buenos Aires.

Gibbons, C., 1969, Delincuentes juveniles y criminales, FCE, México.

Gómezjara, Francisco A., 1987, "Introducción”, en Las bandas en tiempos de crisis, Ediciones Nueva Sociología, México.

ICESI, 2002, Encuesta nacional sobre la inseguridad, México (realizada del 2 al 24 de marzo).

Instituto de Investigaciones Jurídicas, 2004, Código penal federal, UNAM, México.

Jiménez Ornelas, René, 2003, Delincuencia juvenil y prevención, IISUNAM, México, mimeógrafo.

"La vida en territorio mara", 2004, La Jornada, suplemento Masiosare, 7 de marzo, pp. 5-9.

Lamnek, Sigfried, 1980, Teorías de la criminalidad, Siglo XXI, México.

Lechner, Norbert, 1990, Los patios interiores de la democracia. Subjetividad y política, FCE, Chile.

Martín, Claudio, 1985, El fin del manicomio, Nueva Sociología México.

Merton, Robert, 1966, Teoría y estructuras sociales, FCE, México.

Mestre, Esteban, 1976, Diccionario de ciencias sociales, IEP, Madrid.

Mills, Wright C., 1964, Poder, política, pueblo, FCE, México.

Mitter, W., 1975, "Criminalidad juvenil", en Marxismo y Democracia (serie Sociológica, núm 3), Rioduero, Madrid, pp. 39-45.

Monge, Raúl, 2002, "Juventud delincuente, explosivo crecimiento", Proceso, núm. 1331, pp. 4-8.

Pearson, Gerald H., 1970, La adolescencia y el conflicto de las generaciones, Siglo Veinte, Buenos Aires.

Pitch, Tamar, 1980, Teoría de la desviación social, Nueva Imagen, México.

Puffer, Adams J., 1912, The Boy and his Gang, Houghton Mifflin Company, Boston.

Reguillo, Rossana, 2003, La construcción del enemigo, Iteso, México, mimeógrafo.

Sevilla, Ramón, 2003, "Engancha crimen organizado a tres de cada 100 menores", Reforma, 6 de noviembre.

Shaw, C. R., 1930, The Jack-Roller, University of Chicago Press, Chicago.

Spranger, E., 1929, Psicología de la edad juvenil, Revista de Occidente, Madrid.

Thrasher, F., 1927, The Gang, University of Chicago Press, Chicago.

Whyte, William Foote, 1943, Street Corner Society: The Social Structure of an Italian Slum, University of Chicago Press, Chicago. 